\title{
A land plant microfossil assemblage of Mid Silurian age from the Stonehaven Group, Scotland
}

\author{
CHARLES WELLMAN \\ *Department of Palaeontology \\ The Natural History Museum \\ Cromwell Road \\ London SW7 5BD, \\ UK \\ Department of Geology \\ University of Wales, College of \\ Cardiff \\ Cardiff, CF1 3YE \\ (* Present Address)
}

\begin{abstract}
Land plant microfossils recovered from the Stonehaven Group near Stonehaven, Scotland comprise sporomorphs (cryptospores and miospores) and plant fragments (tubular structures and cuticle-like sheets). A new species of hilate cryptospore, Hispanaediscus lamontii sp. nov., is proposed. The sporomorph assemblage indicates a late Wenlock, or possibly earliest Ludlow age and is interpreted as accumulating in a continental environment. The new age constraint suggests that the Stonehaven Group is not in continuous succession with overlying "Lower Old Red Sandstone" deposits and should be treated separately. The assemblage provides important information regarding the composition of Mid Silurian continental plant microfossil assemblages and indicates that the vegetation comprised few taxa and was cosmopolitan. J. Micropalaeontol, 12 (1): 47-66, August 1993.
\end{abstract}

\section{INTRODUCTION}

The Stonehaven Group comprises a sequence of continental sediments which crop out in the north-east corner of the Midland Valley of Scotland (Fig.1). The strata unconformably overlie Cambro-Ordovician rocks of the Highland Border Complex and, following a break in exposure, are succeeded by a sequence of "Lower Old Red Sandstone" continental deposits. The age of the Stonehaven Group has until recently been uncertain and its relationship with the overlying "Lower Old Red Sandstone" deposits unclear. The strata has previously been assigned a Downtonian (Pridoli) age on the basis of fish and arthropod remains from the Cowie Harbour fish bed (Campbell 1913; Westoll 1951). However, fish/arthropod faunas of this age are not well understood and age determinations based on them are not satisfactory. The discovery of rich palynomorph assemblages provided an ideal opportunity to initiate a biostratigraphic investigation of the strata.

\section{GEOLOGICAL SETTING}

The Stonehaven Group is exposed in a nearly continuous coastal section near Stonehaven and can be traced inland in a narrow strip, which runs parallel to the Highland Boundary Fault for $8 \mathrm{~km}$, until it is truncated by a large north-east trending fault (Figs.2-3). There are approximately $1500 \mathrm{~m}$ of steeply dipping strata with strike parallel to the Highland Boundary Fault.

The Stonehaven Group rests unconformably on the Highland Border Complex which is of Cambro-Ordovician

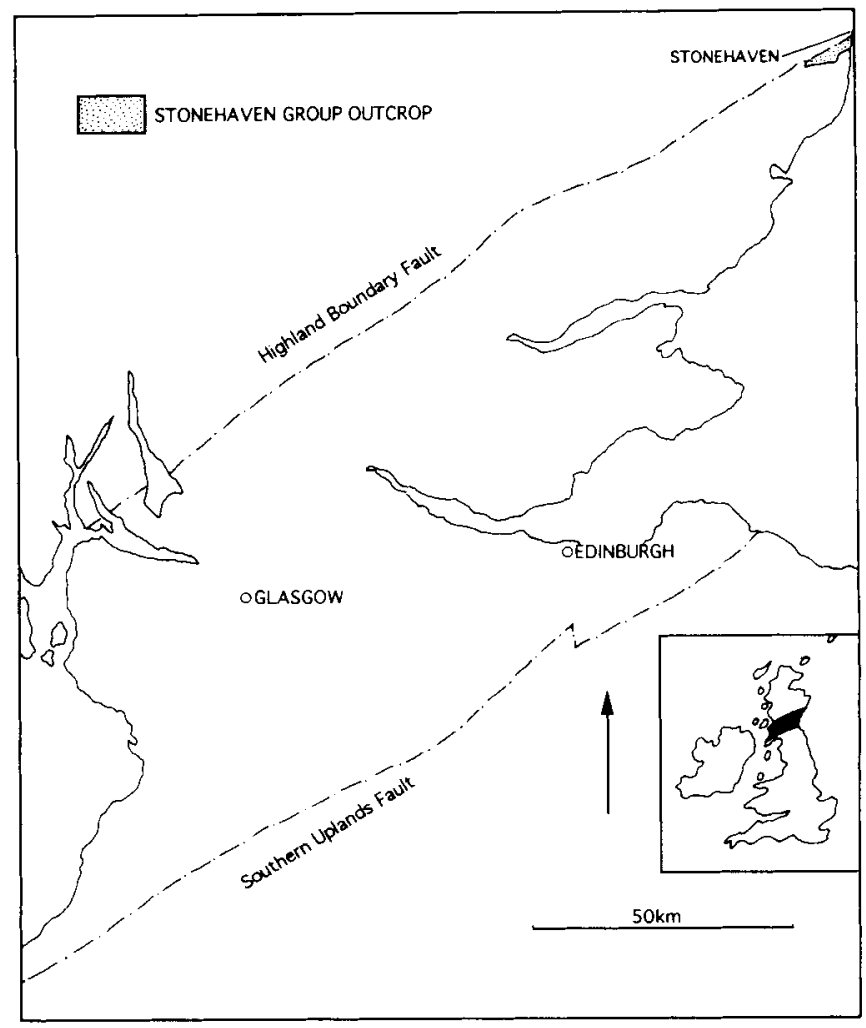

Fig.1 Location map of the Stonehaven Group outcrop. 


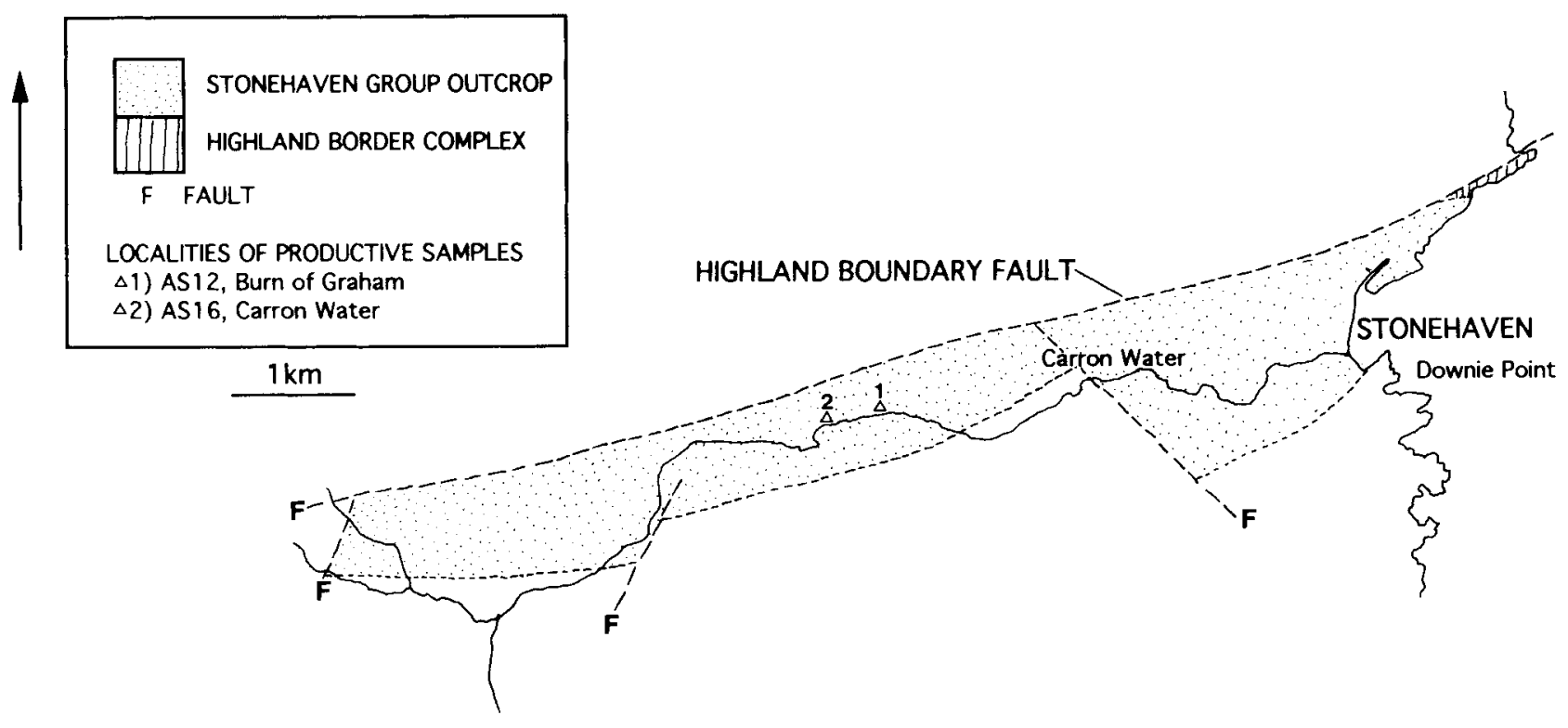

Fig. 2 Geological map of the Stonehaven Area and location of the productive palynological samples.

age. Clasts derived from the Highland Border Complex, which in the vicinity of Stonehaven comprise sheered spilitic pillow lavas, black shale and jasper, are present in the basal breccia of the Stonehaven Group. The Highland Border Complex is itself in tectonic contact with Dalradian rocks along the Highland Boundary Fault.

The location and nature of the top of the Stonehaven Group is more problematical. Campbell (1911) placed the boundary between his "Stonehaven beds" and the overlying Dunnottar Group at the base of the Downie Point Conglomerate, which rests with slight unconformity on the underlying strata. However, Campbell (1913) subsequently suggested that the boundary be moved to the gap in exposure near the mouth of the River Carron whereby at least $100 \mathrm{~m}$ of sandstone which underlies the Downie Point Conglomerate is transferred from the "Stonehaven beds" to the Dunnottar Group. Armstrong \& Paterson (1970) reinvestigated the stratigraphy of the area and adopted Campbell's original boundary at the base of the Downie Point Conglomerate because they believed that this marks "the most significant event in the sedimentological history, as well as providing the most readily mapped boundary". Recent sedimentological analysis demonstrates that the sandstones immediately below the Downie Point Conglomerate have more in common with the Dunnottar Group deposits than the Stonehaven Group deposits which lie below and are separated from them by the break in exposure (Armstrong et al.1978; Gillen \& Trewin 1987). Furthermore, new palaeontological evidence (Hanken \& Størmer 1975; Marshall 1991; Wellman 1991, this work) indicates that the Stonehaven Group may be considerably older than was previously accepted. These new lines of evidence suggest that the Stonehaven Group may not be intimately related to the succeeding "Lower Old Red Sandstone" deposits as was previously accepted but the break in exposure near the mouth of the River Carron may conceal a significant unconformity or possibly a faulted contact. Therefore it seems logical to draw the top of the Stonehaven Group at this break in exposure and include the sandstone which immediately underlies the Downie Point Conglomerate with the Dunnottar Group as Campbell (1913) suggested.

The Stonehaven Group of Armstrong \& Paterson(1970) corresponds to the "Stonehaven beds" of Campbell(1913) except for the location of the boundary with the Dunnottar Group (see above). Armstrong \& Paterson divided the Group into two formations, the Cowie Formation and the succeeding Carron Formation. Donovan (in Armstrong et al.1978) outlined several members which were formalised in Gillen \& Trewin (1987). A stratigraphical log is illustrated in Fig.4.

Unconformably overlying the Highland Border Complex the Cowie Formation commences with a $60 \mathrm{~m}$ thick basal breccia (Basal Breccia Member) with clasts derived mainly from the Highland Border Complex. The breccia is believed to represent an alluvial fan deposit. It is succeeded by dull red, yellow and grey sandstones with rare intercalations of red and grey mudstone (Purple Sandstone, Castle of Cowie, and Brown and Grey Sandstone Members). These deposits exhibit a variety of structures, including cross and parallel lamination, and are interpreted as accumulating in a combination of meandering and braided fluvial complexes. The sandstones are succeeded by a $12 \mathrm{~m}$ thick conglomerate which is composed predominantly of clasts of acid volcanic 


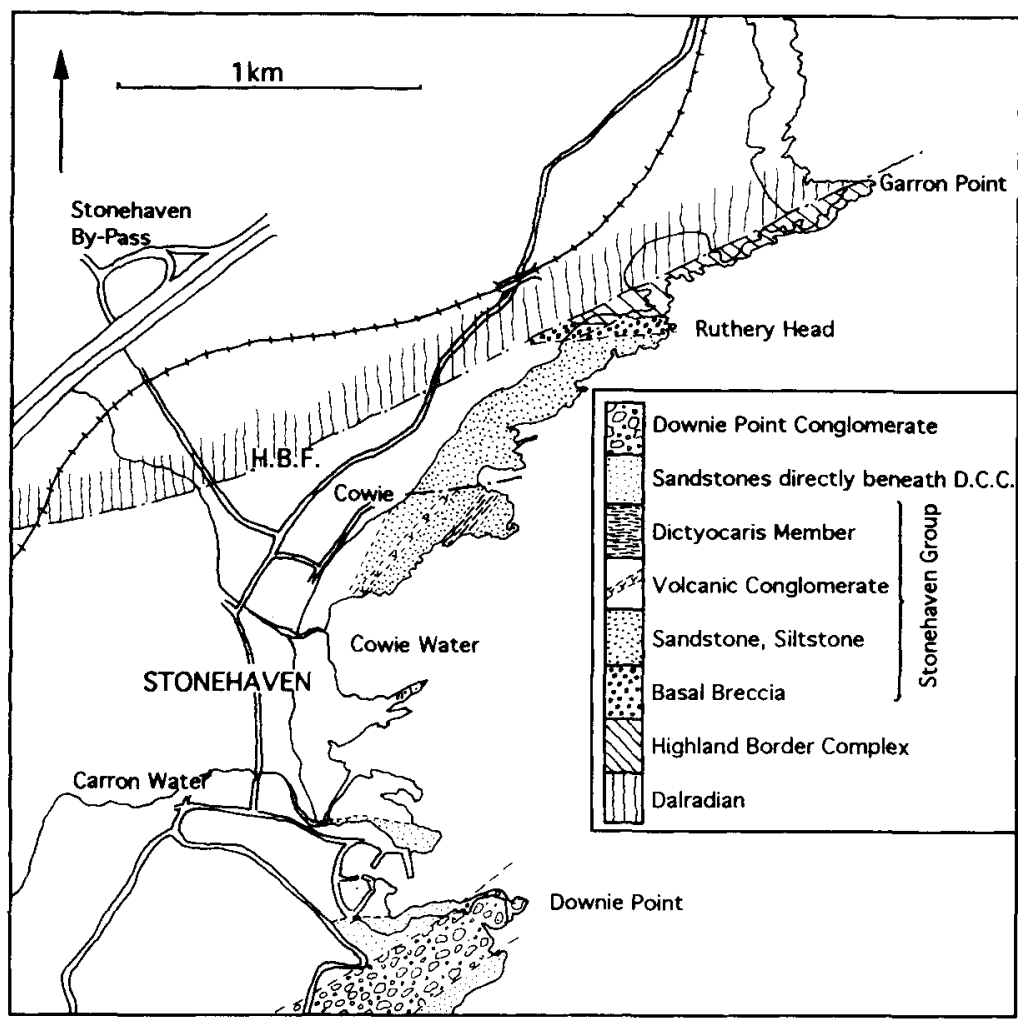

Fig. 3 Geological map of the coastal section near Stonehaven (after Donovan in Armstrong et al.1978).

rocks (Volcanic Conglomerate Member). The conglomerate is overlain by medium grained sandstones (Red Sandstone Member) which were probably deposited by braided streams. The succeeding Dictyocaris Member comprises alternations of fine grey sandstones and green shales and is interpreted as accumulating in a fluvio-lacustrine floodplain complex. The shales contain rare suncracks and are in places charged with Dictyocaris. A fish bed (the Cowie Harbour fish bed) occurs near the base of this member and has yielded remains of fish, arthropods and rare plant fragments (summarised in Westoll 1951).

The succeeding Carron Formation commences at the sandstones which overlie the last shale of the Cowie Formation. It is dominated by reddish-brown, medium to coarse grained sandstones which are often cross-laminated, contain a high proportion of volcanic debris and are in places conglomeratic. The formation is unfossiliferous. Consideration of the lithology and sedimentary structures suggests that this formation represents a continuation of fluviatile conditions. The author suggests that the top of this formation is taken at the break in exposure near the mouth of the River Carron (see above).

Age determination of the Stonehaven Group was for a long time based solely on biostratigraphic interpretation of the fish and arthropod fauna of the Cowie Harbour fish bed. Campbell $(1911,1913)$ suggested that these fossils indicated a Downtonian age. Westoll (1951) reinvestigated the fauna and agreed with Campbell's age assignment. However, Lamont (1952) advised that considerable caution must be exercised when utilising such faunas for age dating and correlation following his recognition that similar 'Ludlow-Downtonian' faunas from the southern Midland Valley were probably of late Llandovery-early Wenlock age. He suggested that the Stonehaven faunas may be older than Downtonian. Subsequently, following a reappraisal of Silurian eurypterid faunas, Hanken and Størmer (1975) suggested that the eurypterids from the Stonehaven Group may be early Ludlow in age. The recovery of additional biostratigraphical evidence, in the form of sporomorph assemblages, permitted an independent age assessment (Marshall 1991, Wellman 1991, this work). The spore evidence indicates a late Wenlock, or possibly early Ludlow age thus supporting the suggestion of Lamont (1952) and Hanken \& Strrmer (1975) that the Downtonian age designation is incorrect.

\section{PREVIOUS PALYNOLOGICAL INVESTIGA- TIONS}

Previous sampling of the Stonehaven Group was concentrated along the coastal section and was unproductive (John Richardson pers. com. 1988). However, during the course of my investigation, Marshall(1991) published a report concerning the palynology of the Stonehaven Group. Marshall recovered productive samples from inland exposures of the Cowie Formation. The assemblages were reported as consisting entirely of sporomorphs including permanent tetrads, pseudodyads, dyads, alete spores and trilete spores'. The trilete spores were all laevigate but 'alete spores with rudimentary sculpture' were present. Marshall assigned the ornamented species to cf.Synorisporites verrucatus Richardson and Lister in Richardson \& Ioannides, 1973 and Emphanisporites cf. protophanus Richardson and Ioannides, 1973. On the basis of this palynoflora Marshall suggested an age range of late Wenlock to early Ludlow, principally using information derived from Richardson \& McGregor(1986) and Richardson \& Edwards (1989). Additionally he suggested that the assemblage indicates derivation from continental deposits.

\section{SAMPLING AND TECHNIQUES}

Sampling was confined to the rather poorly exposed inland outcrop where samples from two localities were productive (see Appendix 1). These exposures have been correlated with the Cowie Formation (Campbell 1913). The productive samples contain a similar well preserved assemblage consisting entirely of sporomorphs and plant fragments. Thermal maturity is fairly high (TAI 3-4) and the 


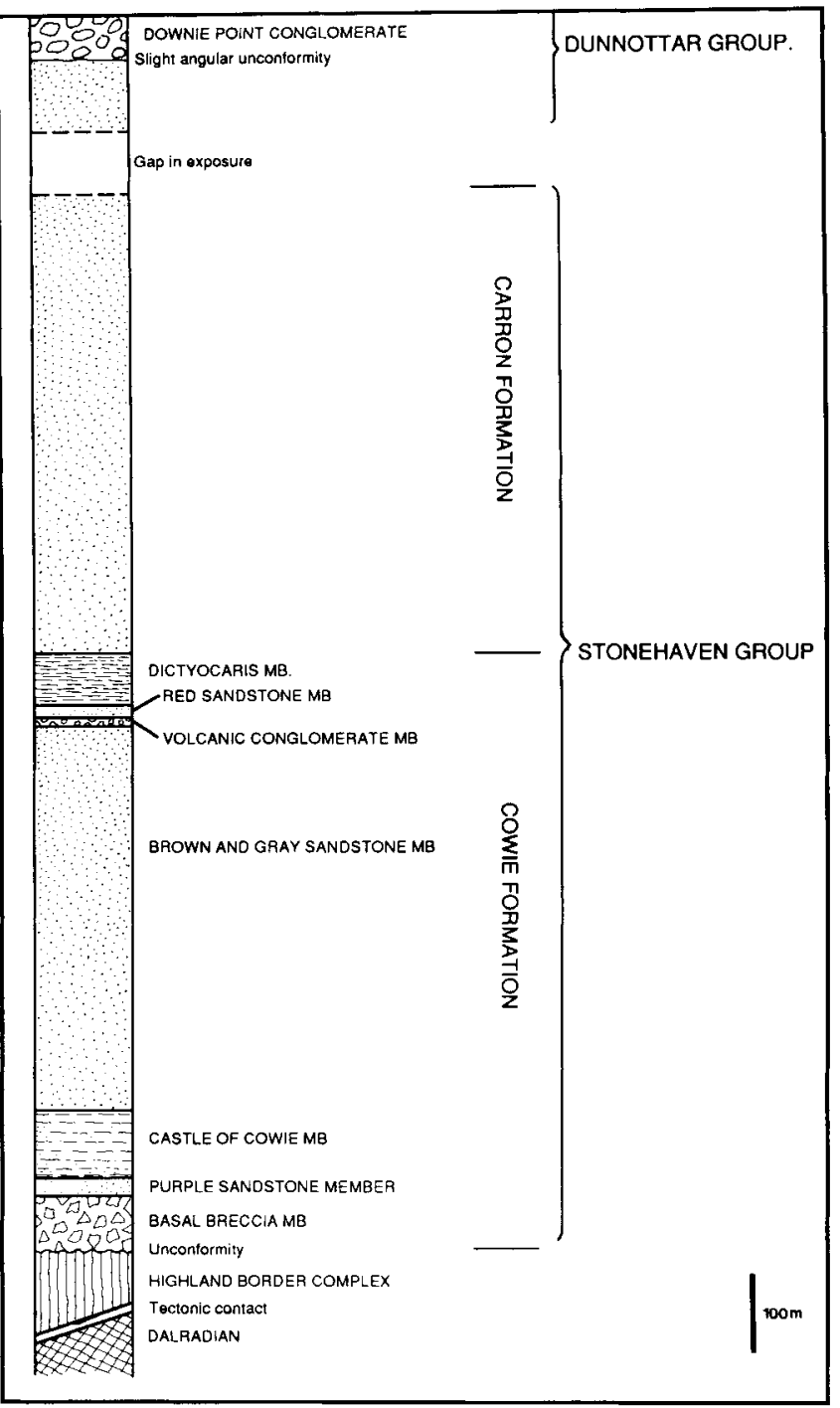

Fig. 4 Stratigraphical succession exposed in the Stonehaven area (after Donovan in Armstrong et al.1978).

sporomorphs are dark brown.

Samples were prepared for palynological investigation using standard $\mathrm{HCl}-\mathrm{HF}-\mathrm{HCl}$ acid maceration techniques followed by Zinc Bromide heavy mineral separation. The organic residue was sieved through a $10 \mu \mathrm{m}$ mesh. Some of the samples were oxidised for between 15 and 60 minutes in
Schultze's solution in order to clear them and facilitate light microscope observation. This treatment was successful and the oxidised palynomorphs were diaphanous yelloworange. Additionally, stubs were strew mounted and gold coated for Scanning Electron Microscope analysis.

\section{SYSTEMATIC PALAEONTOLOGY}

Wherever possible the terminology utilized in the description of the sporomorphs is from Grebe(1971) and Wellman and Richardson(1993). The descriptions of the trilete spores are arranged in accordance with a standard, artificial, morphology-based, turma system of classification. The cryptospores are arranged in a similar classification recently proposed by Strother(1991). Synonymy lists are only provided for species not described in Wellman \& Richardson(1993).

Figured specimens are stored in the Palynology Section, Palaeontology Department, the Natural History Museum, London. Specimen location refers to standard England Finder co-ordinates from the Zeiss Photomicroscope 111 (no.2562) housed in the same department. Scanning Electron Microscope print numbers refer to proof prints stored in the Electron Microscopy Unit of the Natural History Museum, London.

All specimens described and figured in this paper are from the Cowie Formation from the Burn of Graham, near Stonehaven (see Appendix 1).

\section{SYSTEMATIC DESCRIPTIONS}

Anteturma Cryptosporites (Richardson et al.1984) Richardson 1988

Turma Tetrasporites Strother 1991

Genus Cheilotetras Wellman and Richardson, 1993

Type species. Cheilotetras caledonica Wellman \& Richardson, 1993

Cheilotetras caledonica Wellman \& Richardson, 1993 (P1.3, Figs 7,8)

1993 Cheilotetras caledonica Wellman and Richardson: 162, pl.1, figs.1-7.

Dimensions. $40(51) 76 \mu \mathrm{m}, 37$ specimens measured.

Remarks. The internal structure of these tetrads is unclear. However, the recovery of fractured specimens demonstrate that crosswalls are present between adjacent spores, but it is unclear if the crosswalls comprise a single wall which is shared by adjoining spores or if they comprise two, closely

\section{Explanation of Plate 1}

(magnification $X 1000$ unless otherwise stated)

Figs.1-3 Laevolancis divellomedium (Chibrikova) Burgess \& Richardson, 1991. 1, FM352 (slide AS12(2/3), co-ord.046 1177, E.F.no: F48). 2, FM353 (slide AS12/4, co-ord.083 1299, E.F.no: K60/4). 3, FM354 (slide AS12/4, co-ord.050 1082, E.F.no: G38).

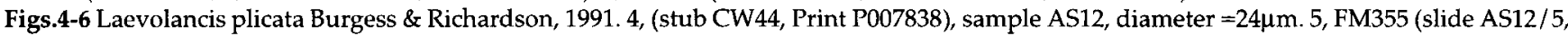
co-ord.127 1210, E.F.no: T51). 6, cluster of specimens, FM356 (slide AS12/2, co-ord.143 1354, E.F.no: Q66/4).

Figs.7-8 Artemopyra brevicosta Burgess \& Richardson, 1991. 7-8, FM357 (slide AS12(2/6), co-ord.144 1096, E.F.no: R39/2).

Figs.9,12 Artemopyra sp.A Burgess \& Richardson, 1991. 9, FM358 (slide AS12/2, co-ord.218 1346, E.F.no: Y65). 12, FM359 (slide AS12(2/3), coord.080 1230, E.F.no: K53).

Figs.10-11 Hispanaediscus verrucatus? (Cramer) Burgess \& Richardson, 1991. 10, FM360 (slide AS12(2/5), co-ord.114 1165, E.F.no: N47/3). 11, FM361 (slide AS12/3, co-ord.137 1185, E.F.no: Q49/1). 

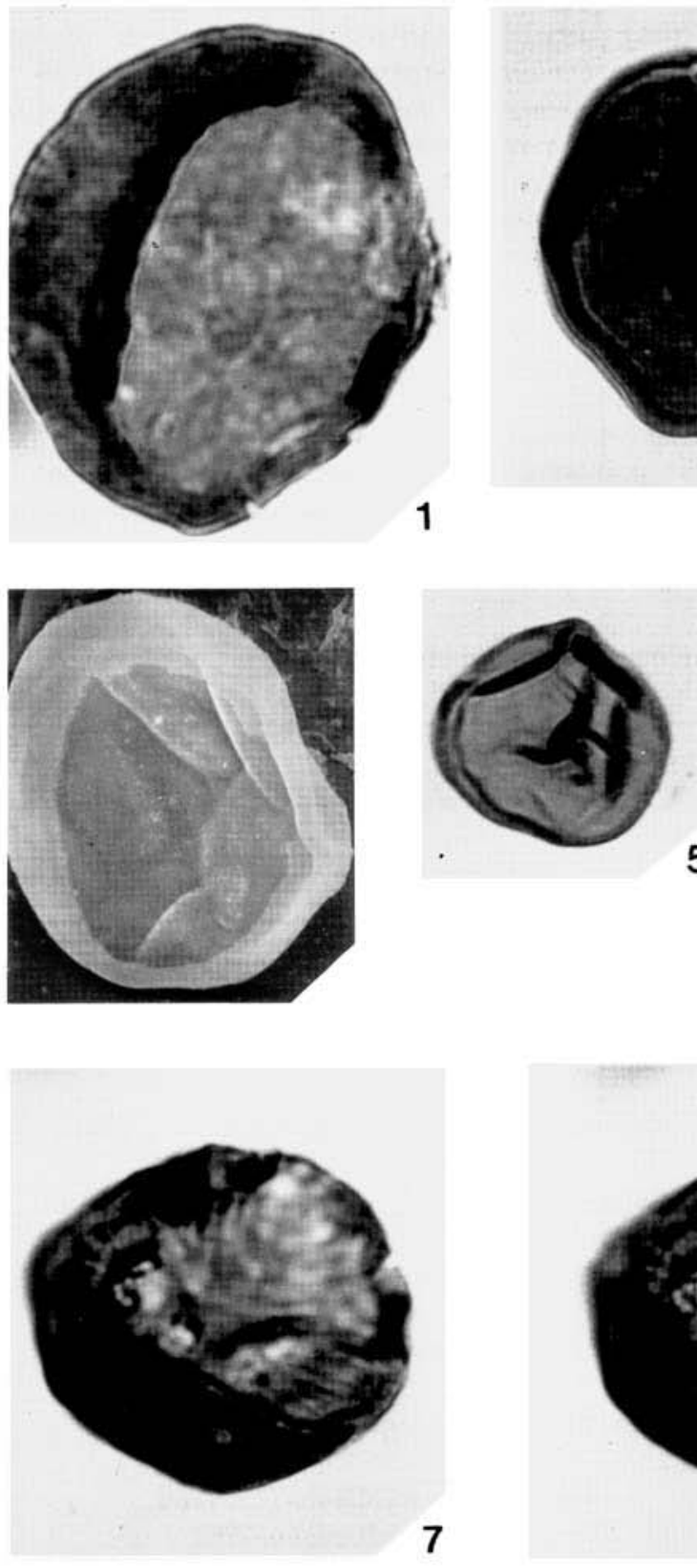

5
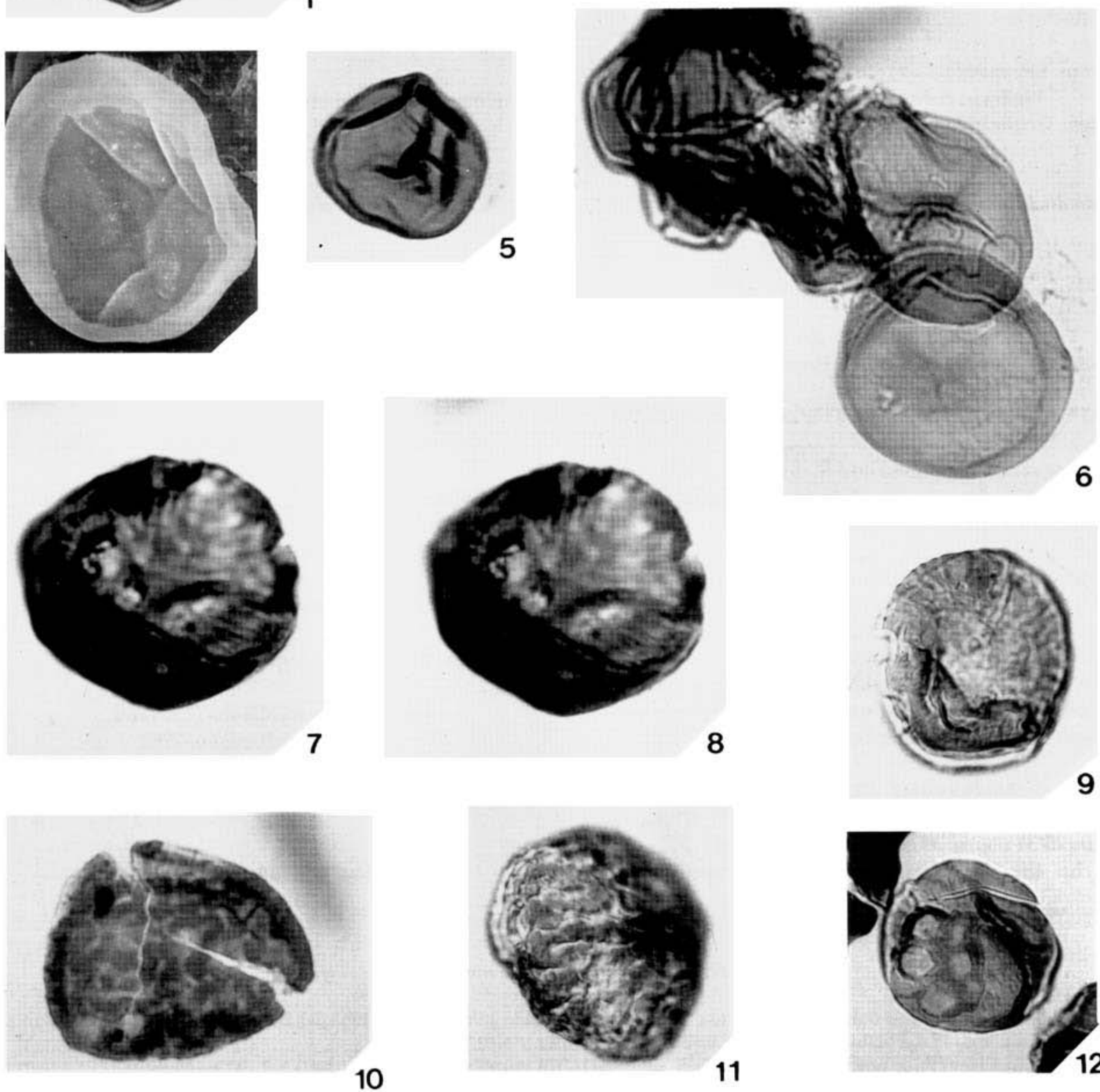
appressed, independent walls where each wall belongs to adjacent, discrete spores. If the crosswalls consist of two walls with a plane of separation between them, one would expect to observe a line of attachment on the surface of the tetrad, which marks the junction between the two walls and hence the junction between the discrete spores of the tetrad. However, SEM studies illustrate that lines of attachment are not present. It is possible that the tetrad is enclosed within a tight fitting envelope which conceals the line of attachment (see Gray, 1991). However, this is considered unlikely as one would expect to observe tearing or wrinkling of the envelope in some specimens, a phenomena which has not been observed. A further possibility is that the crosswall is only partially divided into two walls and the junction is fused towards the exterior of the tetrad, and hence there is no line of attachment.

\section{Genus Tetrahedraletes (Strother \& Traverse)} Wellman \& Richardson, 1993

Type species. Tetrahedraletes medinensis Strother \& Traverse, 1979

Tetrahedraletes medinensis (Strother \& Traverse)

Wellman \& Richardson, 1993

(Pl.4, Figs 1-3)

Dimensions. 25(36)48 $\mu \mathrm{m}$, 50 specimens measured.

Turma Dyadosporites Strother 1991

Subturma Eudyadosporites Strother 1991

\section{DISSOCIATED TRUE DYADS (HILATE CRYPTOSPORES)}

Genus Laevolancis Burgess and Richardson, 1991 Type species. Laevolancis divellomedium (Chibrikova) Burgess \& Richardson, 1991

\section{Laevolancis divellomedium (Chibrikova) Burgess \& Richardson, 1991}

(Pl.1, Figs 1-3)

Dimensions. 35(44)55 $\mu \mathrm{m}, 50$ specimens measured. Remarks. In the Stonehaven assemblage these sporomorphs were occasionally observed comprising partially dissociated dyads that can be placed in the species D.murusdensa.

Laevolancis plicata Burgess \& Richardson, 1991 (Pl.1, Figs 4-6)

Dimensions. 25(31)48 $\mu \mathrm{m}, 39$ specimens measured.

Remarks. In the Stonehaven assemblage apparently identical sporomorphs were occasionally observed comprising partially dissociated dyads that can be placed in the species D.murusattenuata. Specimens of L.plicata are occasionally present as masses of up to 20 individuals. These masses may represent the sporangial contents of some form of land plant. However, it should be noted that the spores are always seen in loose association in the masses and not in dyad or tetrad configuration.

Genus Artemopyra Burgess \& Richardson, 1991 Type species. Artemopyra brevicosta Burgess \& Richardson, 1991

Remarks. Artemopyra Burgess \& Richardson, 1991 was validly published shortly before the publication of Dicryptosporites Strother, 1991. The concept of both genera is clearly the same and Artemopyra is adopted as it has priority.

Artemopyra brevicosta Burgess \& Richardson, 1991 (Pl.1, Figs 7-8)

1973 Emphanisporites cf. protophanus Richardson \& Ioannides: 274 , pl.2, fig.7.

?1978 ?Emphanisporites protophanus McGregor \& Narbonne: 1295, pl.2, fig.9.

?1979 'Spore with radial thickenings on one surface' Strother and Traverse: p.14.

1991 Artemopyra brevicosta Burgess \& Richardson: 612, pl.1, figs.1-3.

?1991 Dicryptosporites radiatus Strother: 226, pl.1, fig.6.

Dimensions. $40 \mu \mathrm{m}, 1$ specimen measured.

Artemopyra sp.A Burgess \& Richardson, 1991

(Pl.1, Figs 9,12)

?1991 Emphanisporites cf. protophanus Richardson \& Ioannides; Marshall: fig.3 (6).

1991 Artemopyra sp.A Burgess \& Richardson: 613, pl.1, figs.10-11.

?1991 Dicryptosporites minus Strother: 226, pl.1, figs 4-5.

Dimensions. $31(34) 37 \mu \mathrm{m}, 4$ specimens measured.

$$
\begin{gathered}
\text { Genus Hispanaediscus (Cramer) } \\
\text { Burgess \& Richardson, } 1991
\end{gathered}
$$

Type species. Hispanaediscus verrucatus (Cramer) Burgess \& Richardson, 1991

Hispanaediscus lamontii sp. nov.

\section{Explanation of Plate 2
(magnification X1000 unless otherwise stated)}

Figs.1-4 Hispanaediscus wenlockensis Burgess \& Richardson, 1991. 1-2, FM362 (slide AS12/3, co-ord.196 1236, E.F.no: W54). 3, FM363 (slide AS12/2, co-ord. 215 1330, E.F.no: Y64/1). 4, FM364 (slide AS12/3, co-ord.107 1291, E.F.no: N60 / 1).

Figs.5-10 Hispanaediscus lamontii sp.nov. 5,8, holotype, FM365 (slide AS12(2/3), co-ord.082 1141, E.F.no: K44). 6,9, FM366 (slide AS12/2, co-ord.138 1276, E.F.no: Q58/2). 7,10, FM367 (slide AS12(2/3), co-ord.093 1222, E.F.no: L52/4).

Figs.11-13 Pseudodyadospora petasus Wellman \& Richardson, 1993. 11, (stub CW45, Print P007866), sample AS12. 12, FM368 (slide AS12(2/3), co-ord.080 1265, E.F.no: K57/1). 13, FM369 (slide AS12(2/3), co-ord.055 1076, E.F.no: G37/4.). 

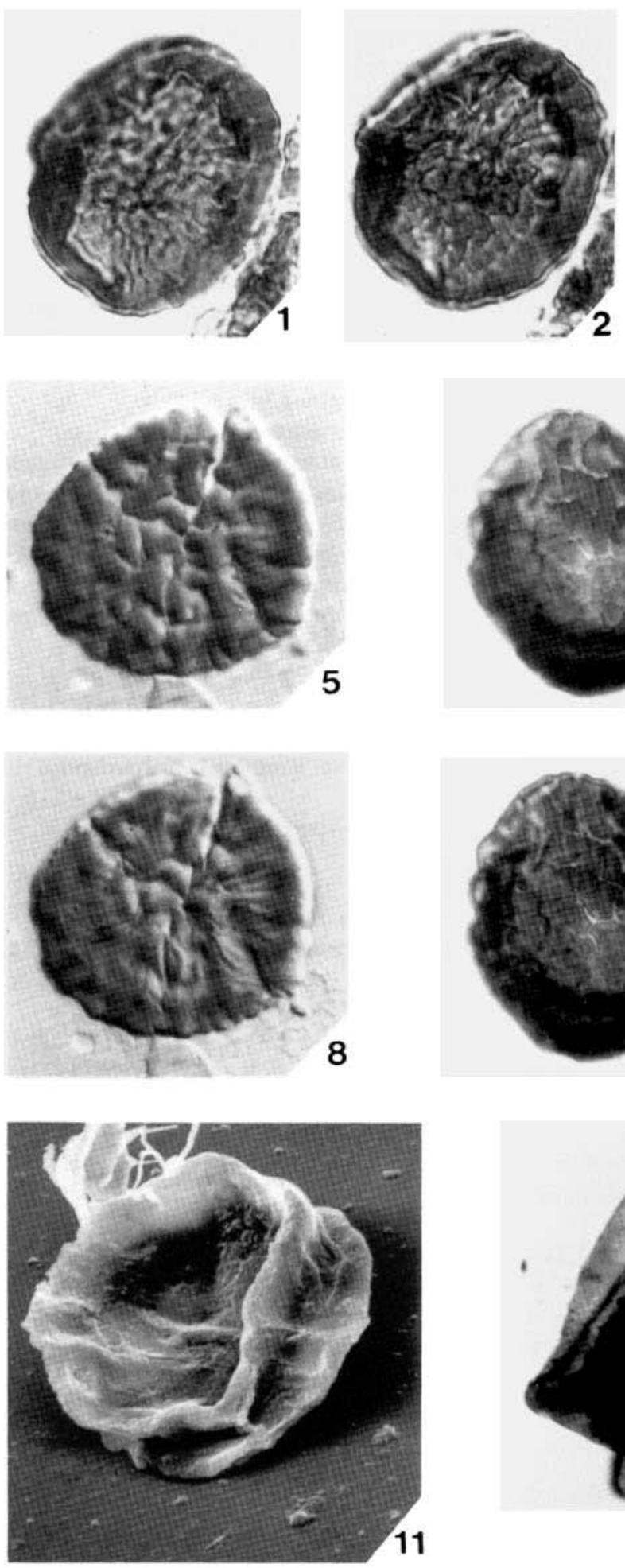
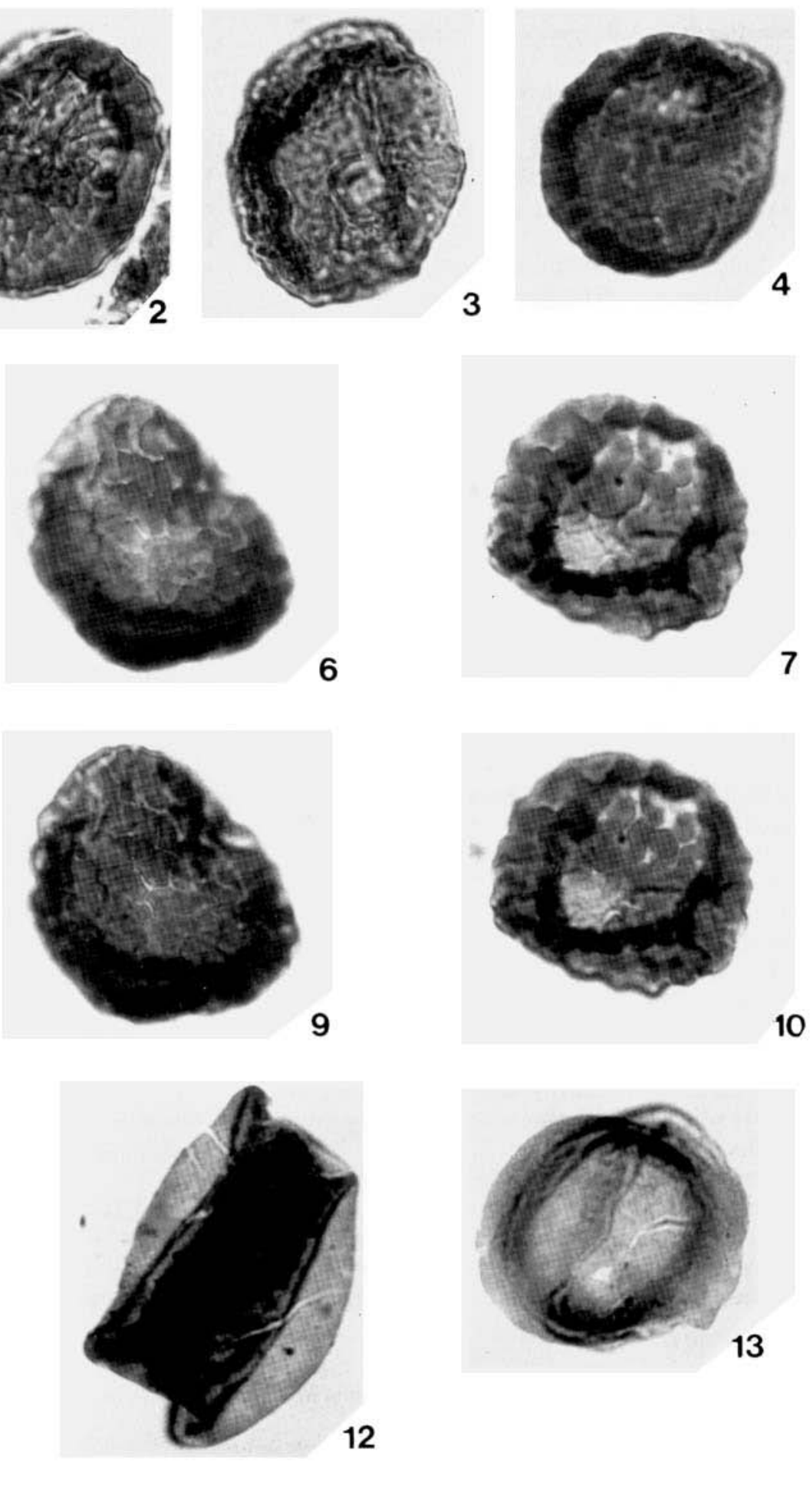
(P1.2, Figs 5-10)

$1991 \mathrm{cf}$.Hispanaediscus sp.A Burgess and Richardson: 611, pl.2, Figs 10-11.

Derivation of name. after Archie Lamont.

Diagnosis. An Hispanaediscus with proximal radial muri/folds and a distal ornament comprising prominent wide muri which are convoluted, bifurcate and are closely spaced. Distal muri $1(2) 4 \mu \mathrm{m}$ wide, c. $1 \mu \mathrm{m}$ high and $1-2 \mu \mathrm{m}$ apart.

Holotype. P1.2, figs.5,8, FM365 (slide AS12(2/3), co-ord.082 1141, E.F.no: K44), sample AS12, Cowie Formation, Burn of Graham, near Stonehaven.

Paratypes. Pl.2, figs.6,9, FM366 (slide AS12/2, co-ord.138 1276, E.F.no: Q58/2). Pl.2, figs.7,10, FM367 (slide AS12(2/3), co-ord.093 1222, E.F.no: L52/4).

Occurrence. Cowie Formation, near Stonehaven.

Description. Amb circular to sub-circular. Equatorial to sub-equatorial crassitude up to $1 \mu \mathrm{m}$ wide delimits a more or less circular hilum. Hilum ornamented with radially disposed muri/folds which are straight or slightly sinuous and taper towards the proximal pole. Muri/folds fairly prominent, up to $1 \mu \mathrm{m}$ wide, less than $0.75 \mu \mathrm{m}$ high and 0.75 $1.5 \mu \mathrm{m}$ apart. Distal surface $1-2 \mu \mathrm{m}$ in thickness and ornamented with prominent muri which are convoluted and bifurcate and are rounded in profile. The muri are up to $4 \mu \mathrm{m}$ wide, but generally $1-2 \mu \mathrm{m}$ wide, c. $1 \mu \mathrm{m}$ high, and 1$2 \mu \mathrm{m}$ apart.

Dimensions. 31(36)42 $\mu \mathrm{m}, 10$ specimens measured.

Comparison. H. wenlockensis Burgess \& Richardson, 1991 has a distal ornament of smaller, closely packed verrucae which are usually discrete and only rarely unite to form muri. H. verrucatus (Cramer) Burgess \& Richardson, 1991 lacks proximal ribbing and is distally ornamented predominantly with discrete, low verrucae. Hilate cryptospores figured by Burgess and Richardson(1991) and described as cf. Hispanaediscus sp.A were examined and are considered identical to H.lamontii sp. nov. A new species is erected for the inclusion of such spores because they are present on either side of the Iapetus suture and may prove to be stratigraphically important.

Remarks. H.lamontii is included in the genus Hispanaediscus because the author considers that it is not at present beneficial to create a new genus which differs from Hispanaediscus solely because the exine over the hilum is noticeably thinner than the distal exine (see Burgess \&
Richardson, 1991, p.611).

Hispanaediscus verrucatus? (Cramer)

Burgess \& Richardson, 1991

(Pl.1, Figs 10-11)

1991 cf.Synorisporites verrucatus Richardson and Ioannides 1973; Marshall: fig. 3 (5).

Description. Amb circular to sub-circular. Equatorial or sub-equatorial crassitude c. $1 \mu \mathrm{m}$ wide delimits a more or less circular hilum. Hilum laevigate. Distal exine with a sculpture of low verrucae which are less than $0.75 \mu \mathrm{m}$ high and are round-topped in profile. The verrucae are generally sub-circular in plan, $2-2.5 \mu \mathrm{m}$ in diameter, and $1-3 \mu \mathrm{m}$ apart. In some specimens the verrucae tend to coalesce in places forming muri up to $6 \mu \mathrm{m}$ long by $1.5 \mu \mathrm{m}$ wide.

Dimensions. 30(35)39 $\mu \mathrm{m}, 8$ specimens measured.

Comparisons and remarks: H.verrucatus (Cramer) Burgess and Richardson, 1991 is similar but possesses slightly larger verrucae which are generally discrete and do not form prominent muri similar to those present in the Stonehaven specimens. H.wenlockensis Burgess \& Richardson, 1991 and H.lamontii sp. nov. have proximal radial ribs and larger, discrete distal sculptural elements.

Hispanaediscus wenlockensis Burgess \& Richardson, 1991 (Pl. 2, Figs 1-4)

1991 Hispanaediscus wenlockensis Burgess \& Richardson: 611, pl.1, figs.4-9.

Dimensions. $28(35) 42 \mu \mathrm{m}, 15$ specimens measured.

\section{INTACT TRUE DYADS}

Genus Dyadospora (Strother \& Traverse)

Burgess \& Richardson, 1991

Type species. Dyadospora murusattenuata (Strother \& Traverse) Burgess and Richardson, 1991

Dyadospora murusattenuata (Strother \& Traverse 1979) Burgess \& Richardson, 1991 (Pl.3, Figs 1,4)

Dimensions. length $=35(47) 63 \mu \mathrm{m}$, width $=31(39) 50 \mu \mathrm{m} \quad(22$ specimens).

Dyadospora murusdensa (Strother \& Traverse)

Burgess \& Richardson, 1991

(Pl.3, Figs 2-3,5-6)

Dimensions. length $=37(56) 70 \mu \mathrm{m}$, width $=34(45) 52 \mu \mathrm{m} \quad(50$

Explanation of Plate 3

(magnification X1000 unless otherwise stated)

Figs.1,4 Dyadospora murusattenuata (Strother \& Traverse) Burgess \& Richardson, 1991. 1, FM370 (slide AS12(2/4), co-ord.099 1315, E.F.no: M62/2), 4, FM371 (slide AS12(2/3), co-ord.100 0956, E.F.no: M25).

Figs.2-3,5-6 Dyadospora murusdensa (Strother \& Traverse) Burgess \& Richardson, 1991. 2, FM372 (slide AS12/4, co-ord.030 1122, E.F.no: E42/2). 3, FM373 (slide AS12/2, co-ord.141 1242, E.F.no: Q55/3). 5, (stub CW45, Print P007841) sample AS12, diameter =33 $\mu$ m. 6, FM374 (slide AS12/2, co-ord 195 1200, E.F.no: W50/2).

Figs.7-8 Cheilotetras caledonica Wellman \& Richardson, 1993. 7, FM375 (slide AS12/3, co-ord.132 1204, E.F.no: P51/1). 8, FM376 (slide AS12/2, co-ord.187 1164, E.F.no: L47/1).

Figs.9-11 Alete cryptospore monads. 9, FM377 (slide AS12/2, co-ord.198 1221, E.F.no: W52/2). 10, FM378 (slide AS12/3, co-ord.010 1197, E.F.no: C50). 11, FM379 (slide AS12(2/4), co-ord.152 1193, E.F.no: R50/3). 


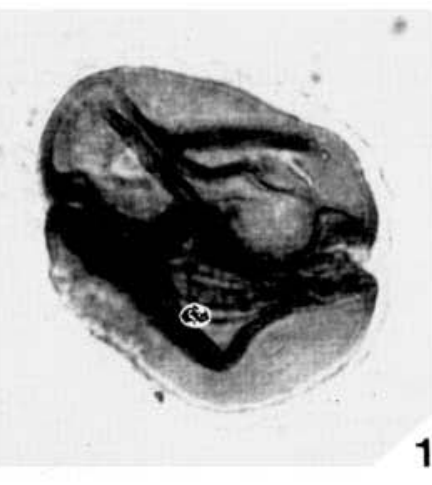

1
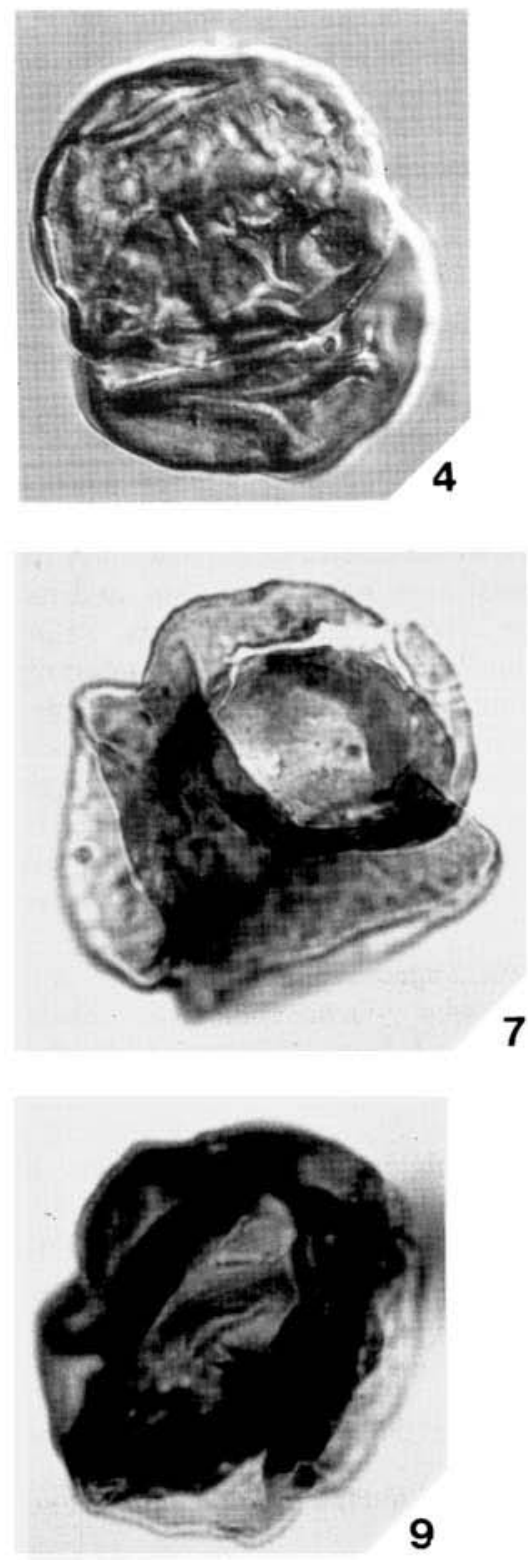
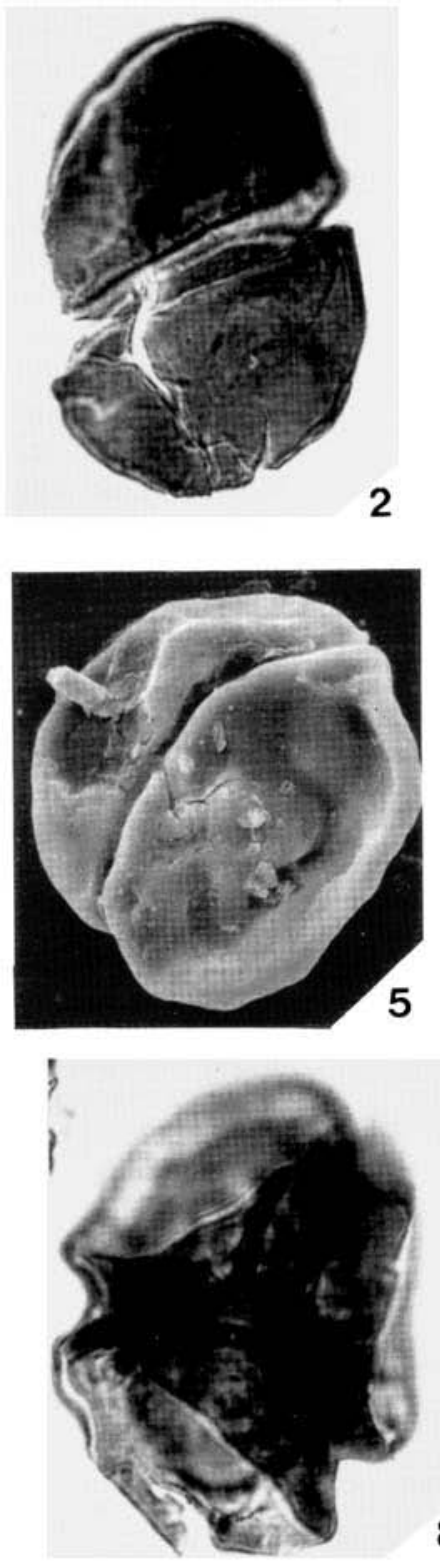

8

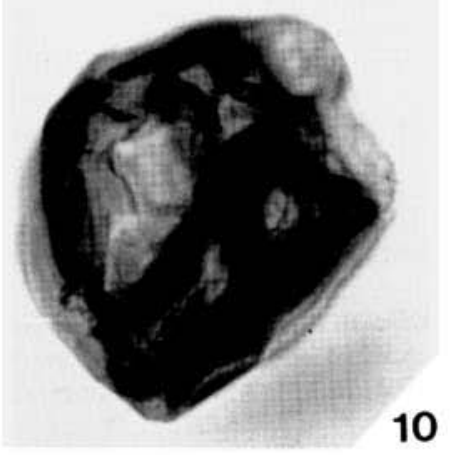

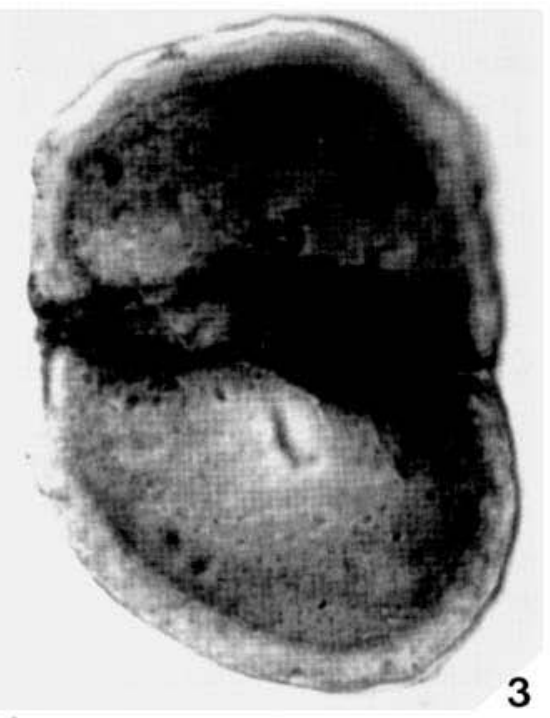

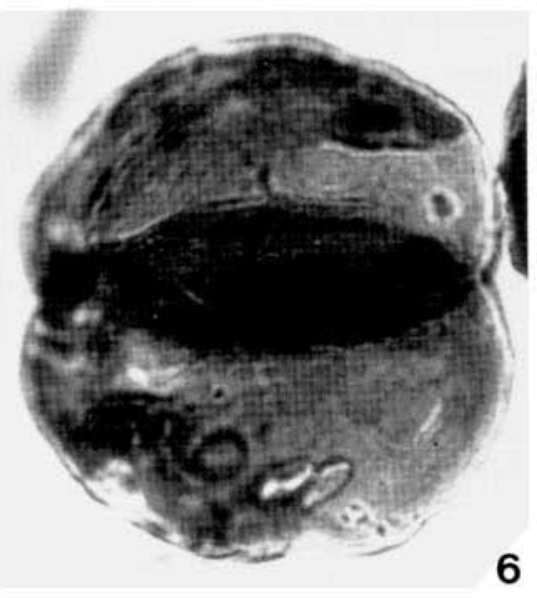

6

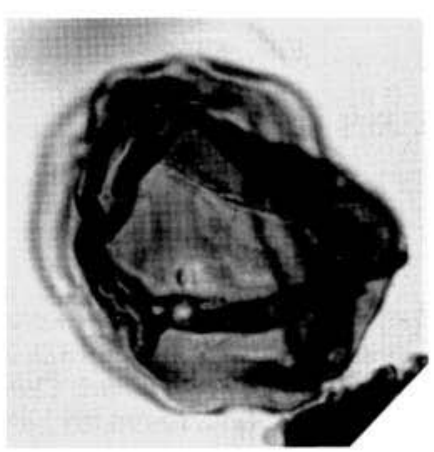


specimens).

Subturma Pseudodyadosporites Strother 1991 Genus Pseudodyadospora Johnson, 1985

Type species:.Pseudodyadospora laevigata Johnson, 1985

Pseudodyadospora petasus Wellman \& Richardson, 1993 (Pl.2, Figs 11-13)

1993 Pseudodyadospora petasus Wellman \& Richardson: 168, pl.2, figs.1-7.

Dimensions. 32(42)51 $\mu \mathrm{m}$ wide, 8 specimens measured.

Anteturma Sporites H.Potonié, 1893

Turma Triletes Reinsch, 1891

Subturma Zonotriletes Waltz, 1935 (in Luber \& Waltz 1938)

Infraturma Crassiti Bharadwaj \& Venkatachala, 1961

Sub-infraturma Laevigati (Bennie \& Kidston) emend. Potonié and Kremp, 1955

Genus Ambitisporites Hoffmeister, 1959

Type species. Ambitisporites avitus Hoffmeister, 1959

Ambitisporites avitus Hoffmeister, 1959

(P1.4, Figs 9-11)

Dimensions. 31(37)53 $\mu \mathrm{m}, 24$ specimens measured.

Ambitisporites dilutus (Hoffmeister)

Richardson \& Lister, 1969

(Pl.5, Figs 1-2,4)

Dimensions. 30(36)42 $\mu \mathrm{m}, 29$ specimens measured.

InfraturmaPatinati (Butterworth \& Williams) Smith \& Butterworth, 1967

Genus Archaeozonotriletes (Naumova) Allen, 1965

Type species. Archaeozonotriletes variabilis (Naumova) Allen, 1965

\section{Archaeozonotriletes chulus (Cramer) Richardson \& Lister, 1969}

(Pl.5, Figs 3,5)

Dimensions. 34(39)51 $\mu \mathrm{m}, 9$ specimens measured.

Genus Chelinospora (Allen) McGregor \& Camfield, 1976 Type species.Chelinospora concinna Allen, 1965

Chelinospora? sp.A

(P1.5, Figs 11-13)

Description. Amb subtriangular. Trilete mark distinct with simple, straight laesurae which extend to the inner margin of the patina. Exine over contact area is thin, less than $1 \mu \mathrm{m}$ in thickness, laevigate and has concentric folds at the margin with the patina. Patina extends over the distal surface of the spore where it is c. $3 \mu \mathrm{m}$ in thickness and forms an equatorial crassitude $2-3 \mu \mathrm{m}$ wide. Patina ornamented distally with thin convolute and anastomosing muri which are c. $1 \mu \mathrm{m}$ wide and less than $1 \mu \mathrm{m}$ high. The muri in places form a highly irregular reticulum which comprises lumina of irregular shape and size. The minimum diameter of the lumina is $4 \mu \mathrm{m}$.

Dimensions. $35 \mu \mathrm{m}, 2$ specimens measured.

Comparison. In most species of Chelinospora the reticulum is more clearly defined and of more regular appearance.

Remarks. Because of the irregular nature of the ornament it initially seemed plausible that the spores were not ornamented and pyrite damage or folding of a thin exoexinal layer were responsible for the apparent muri. However, further observation indicated that this was not the case and the ornament is probably formed by true sculptural elements.

Genus Cymbosporites Allen, 1965

Type species. Cymbosporites cyathus Allen, 1965

\section{Cymbosporites sp.A}

(Pl.5, Figs 7-8,10)

Description. Amb subtriangular. Trilete mark distinct with simple, straight laesurae which extend to the margin of the patina. Exine over contact area is laevigate, thin, and has concentric folds at the margin with the patina. Patina extends over the distal surface of the spore and equatorially where it forms an equatorial crassitude $2-4 \mu \mathrm{m}$ wide. Patina with a distal ornament of of closely spaced, low verrucae with irregular outline. The verrucae are less than $1 \mu \mathrm{m}$ high, $3-5 \mu \mathrm{m}$ in maximum diameter and less than $1 \mu \mathrm{m}$ apart. The verrucae occasionally coalesce forming muri up to $7 \mu \mathrm{m}$ long. The verrucae and muri do not exhibit any pronounced alignment.

Dimensions. 40 and $45 \mu \mathrm{m}, 2$ specimen measured.

Comparisons and remarks. Archaeozonotriletes chulus var.inframurinatus Richardson \& Lister, 1969 has an identical structure and similar distal ornament. Richardson \& Lister(1969) initially regarded this species as possessing a distinct infrastructure which gave the appearance of ornament. However, recent SEM observations indicate that these spores have true sculpture (Richardson pers.com.1991).

\section{Explanation of Plate 4 \\ (magnification $\mathrm{X} 1000$ unless otherwise stated)}

Figs.1-3 Tetrahedraletes medinensis (Strother \& Traverse) Wellman \& Richardson, 1993. 1, (stub CW44, Print P009246), sample AS12. 2, FM380 (slide AS12 / 2, co-ord.012 1260, E.F.no: T68). 3, FM381 (slide AS12/3, co-ord.153 1281, E.F.no: R59/3).

Figs.4-6 MURORNATE TETRADS. 4, (stub CW45, Print P007864), sample AS12. 5 diameter = 67 $\mu$, FM382 (slide AS12/4, co-ord.084 1300, E.F.no: K61/3). 6, FM383 (slide AS12/2, co-ord.099 1289, E.F.no: M59/2).

Figs.7-8 TETRADS OF ?TRILETE SPORES. 7, FM384 (slide AS12(2/4), co-ord.155 1162, E.F.no: R46/4). 8, FM385 (slide AS12(2/3), co-ord.099 1265, E.F.no: M57/1).

Figs.9-11 Ambitisporites avitus Hoffmeister, 1959. 9, (stub CW45, Print P007863), sample AS12. 10, FM386 (slide AS12(2/3), co-ord.110 1166, E.F.no: N36/4). 11, FM387 (slide AS12(2/3), co-ord.030 0958, E.F.no: E25/1). 

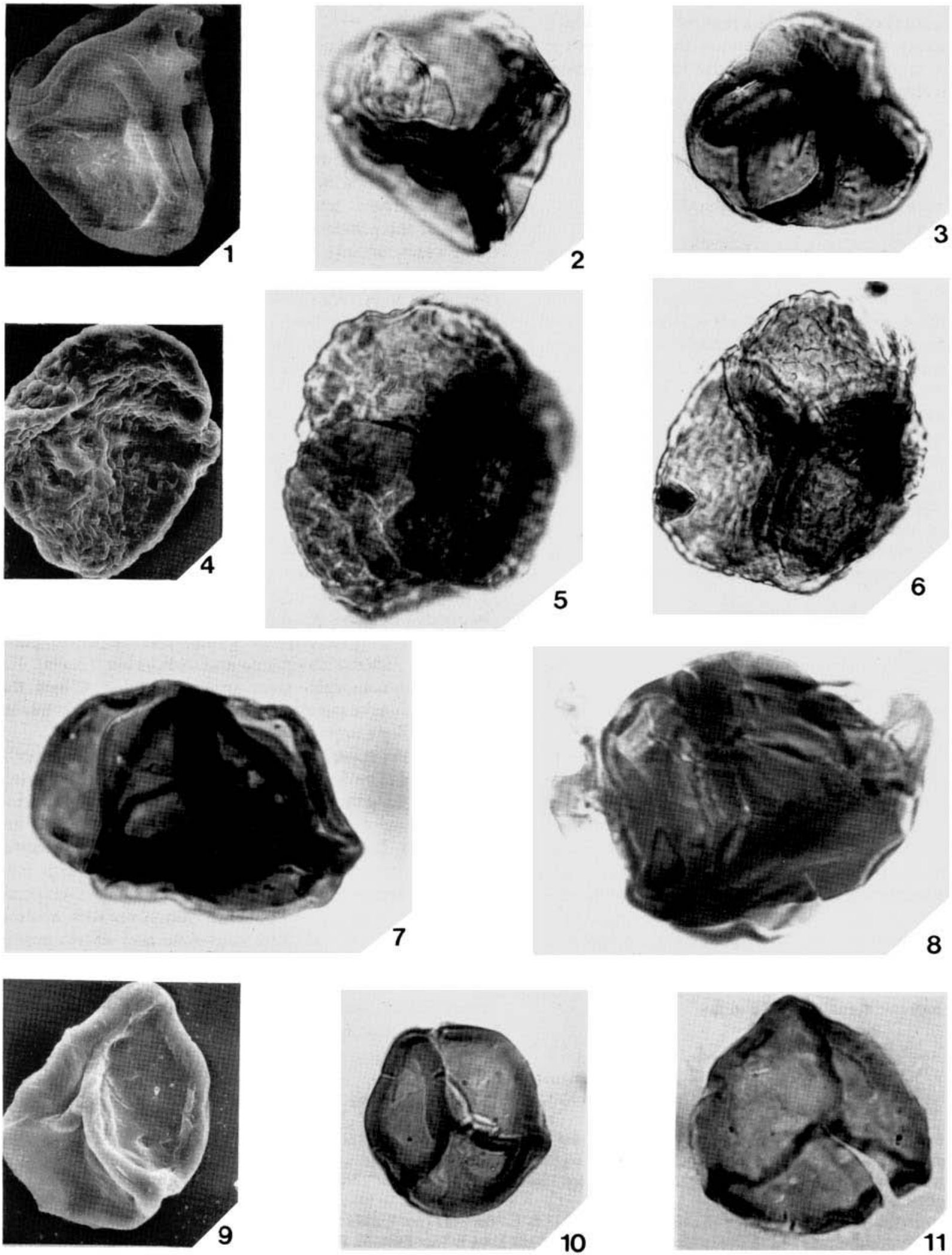
However, Cymbosporites sp.A differs from A.chulus var.inframurinatus because it has less regular verrucae which are more closely packed. Furthermore, the ornament of Cymbosporites sp.A does not exhibit the radial alignment developed in A.chulus var.inframurinatus.

\section{INCERTAE SEDIS}

\section{Murornate Tetrads}

(Pl.4, Figs 4-6)

1991 'Murornate tetrads' Burgess \& Richardson: 619, textfig.3, M-O.

Descriptions. Permanent tetrahedral tetrads comprising ornamented sub-circular to sub-triangular spore-like units. The individual spores are usually distally inflated and possess an equatorial crassitude which is $1-3 \mu \mathrm{m}$ wide. The spores are discrete and a plane of attachment is present between adjacent spores, which forms distinct lines of attachment on the surface of the tetrad. The tetrads are securely bonded and were not observed loosely attached or partially dissociated. The distal exine over the spores has murornate sculpture comprising verrucae and muri. The verrucae are rounded to irregular in outline and are rounded in profile. They are $1.5-2.5 \mu \mathrm{m}$ wide and usually less than $1 \mu \mathrm{m}$ high. The verrucae often unite to form muri, which may be convolute and anastomosing, and are up to $6 \mu \mathrm{m}$ long. The sculptural elements are generally less than $1 \mu \mathrm{m}$ apart.

Dimensions. Tetrad diameter $=52(53) 54 \mu \mathrm{m}$, unit diameter $=33(34) 36 \mu \mathrm{m}-6$ specimens measured.

Comparison. The murornate tetrads present in the Stonehaven assemblage appear identical to those described by Burgess and Richardson (1991) from the type area for the Wenlock.

Remarks. It is possible that the murinate tetrads represent undissociated tetrads of trilete spores. However, trilete spores with ornament similar to that displayed by the murornate tetrads were not recorded in the assemblage, which suggests that this scenario is unlikely as one would expect to recover trilete spores dissociated from the tetrads along with the intact tetrads. Hence it is possible that the tetrads either dissociate to produce ornamented alete sporomorphs, which may perhaps have been confused with hilate cryptospores which are similarly ornamented, or represent permanent cryptospore tetrads which are dispersed intact and remain rigidly intact.

\section{Tetrads of Laevigate ?Trilete Spores}

(Pl.4, Figs 7-8)

Description. Tetrahedral tetrads comprising laevigate, subcircular, sporomorphs which have a well defined equatorial crassitude. Spores usually, but not always, distally inflated. Spores discrete with a distinct plane of attachment between adjacent spores. The tetrads are loosely attached and frequently partially disaggregated.

Dimensions. 38(51) $89 \mu \mathrm{m}, 22$ specimens measured.

Remarks. These tetrads are problematical because the nature of the proximal face of the constituent spores is, in many cases, uncertain. However, because triradiate marks have been discerned in some very loosely attached specimens it is suggested that many, if not all, of these tetrads comprise trilete spores. The trilete spores are probably referable to Ambitisporites, the tetrads having uncharacteristically failed to dissociate prior to dispersal. However, it is possible that some of the tetrads comprise alete units in which case the tetrads are similar to Rimosotetras problematica Burgess, 1991. It is unclear if such tetrads of alete spores are habitually dispersed intact or normally dissociate prior to dispersal, but on occasions uncharacteristically remain intact.

\section{DESCRIPTION OF THE STONEHAVEN ASSEMBLAGE}

The Stonehaven palynomorph assemblage comprises cryptospores (fused and unfused permanent tetrads, pseudodyads, true dyads, hilate cryptospores and alete cryptospore monads), trilete spores, and dispersed plant fragments (tubular structures and cuticle-like sheets). No marine palynomorphs were recorded. Table 1 lists the sporomorph taxa recorded and Table 2 presents the results of a frequency count of the sporomorph morphotypes.

The trilete spores are dominated mainly by smoothwalled crassitate forms assigned to A.avitus and A.dilutus. The laevigate patinate spore A.chulus is also present but is rare. Ornamented trilete spores were recorded but are uncommon. They include crassitate miospores with a distal ornament of verrucae (Synorisporites spp.) (Pl.5, Figs 6,9), patinate miospores with distal murornate sculpture (Cymbosporites sp.A), and patinate miospores with a distal reticulate ornament of thin, convolute and anastomosing muri (Chelinospora? sp.A). The specimens of Synorisporites exhibit a varied ornament consisting of poorly defined, low verrucae and cannot be included in any of the pre-existing species. In the frequency count laevigate trilete spores

Figs.1-2,4 Ambitisporites dilutus (Hoffmeister) Richardson \& Lister, 1969. 1, FM388 (slide AS12(2/3), co-ord.142 1053, E.F.no: Q35). 2, FM389 (slide AS12/4, co-ord.094 1218, E.F.no: L52). 4, FM390 (slide AS12/4, co-ord.112 1053, E.F.no: N35).

Figs.3,5 Archaeozonotriletes chulus (Cramer) Richardson \& Lister, 1969. 3, FM391 (slide AS12(2/3), co-ord.100 1150, E.F.no: M45). 5, FM392 (slide AS12/4, co-ord.060 1140, E.F.no: H44).

Figs. 6,9 Synorisporites spp. 6, FM393 (slide AS12(2/6), co-ord.158 1135, E.F.no: S44/1). 9, FM394 (slide AS12(2/6), co-ord.163 1116, E.F.no:S41/4). Figs. 7-8,10 Cymbosporites sp.A. 7-8, FM395 (slide AS12(2/6), co-ord.132 1149, E.F.no: P45). 10, FM396 (slide AS12(2/5), co-ord.127 1202, E.F.no: P50/2).

Figs. 11-13 Chelinospora? sp.A. 11-12, FM397 (slide AS12/3, co-ord.180 1120, E.F.no: U42/4). 13, FM398 (slide AS12/4, co-ord.027 1198, E.F.no: D50). 

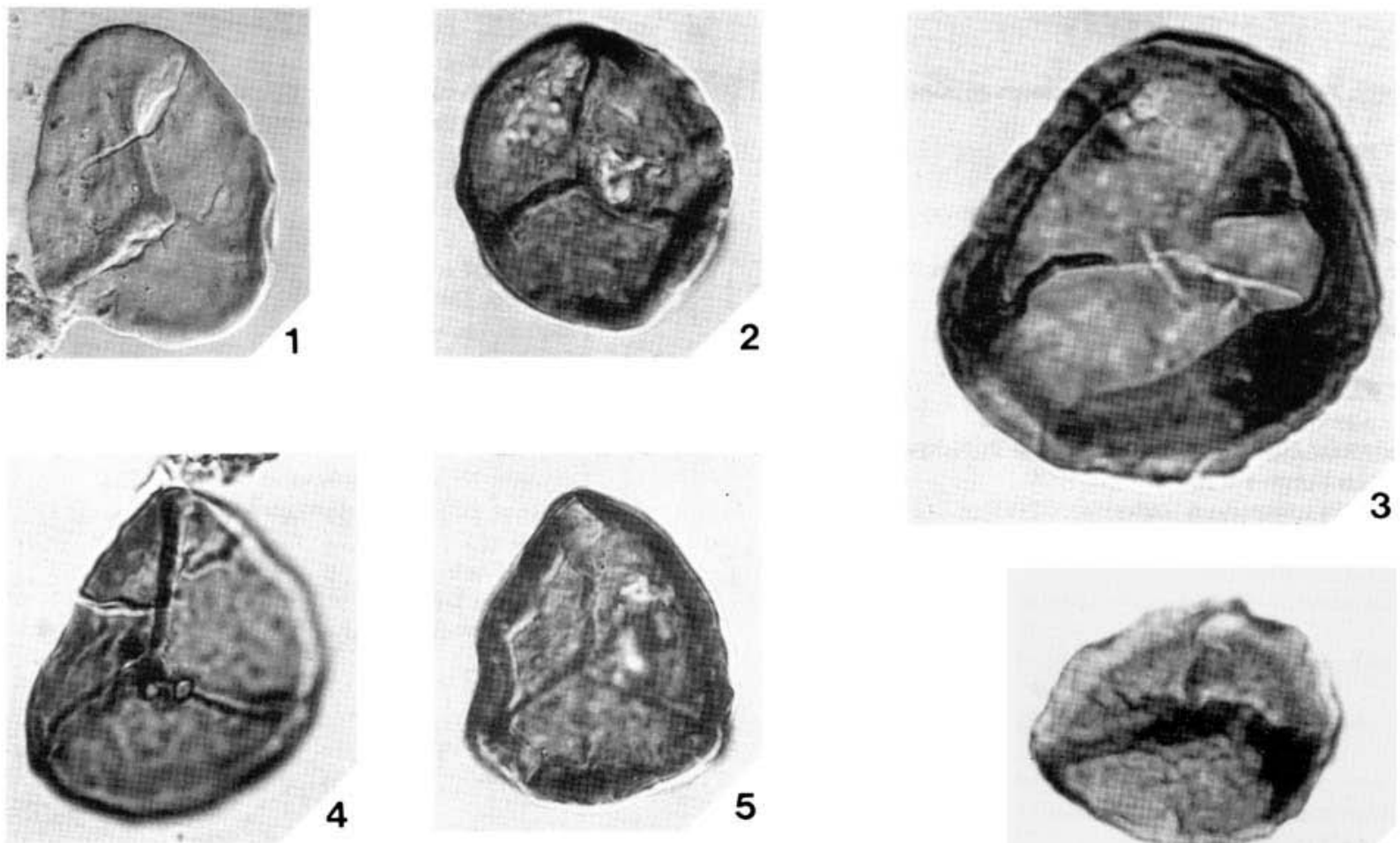

3
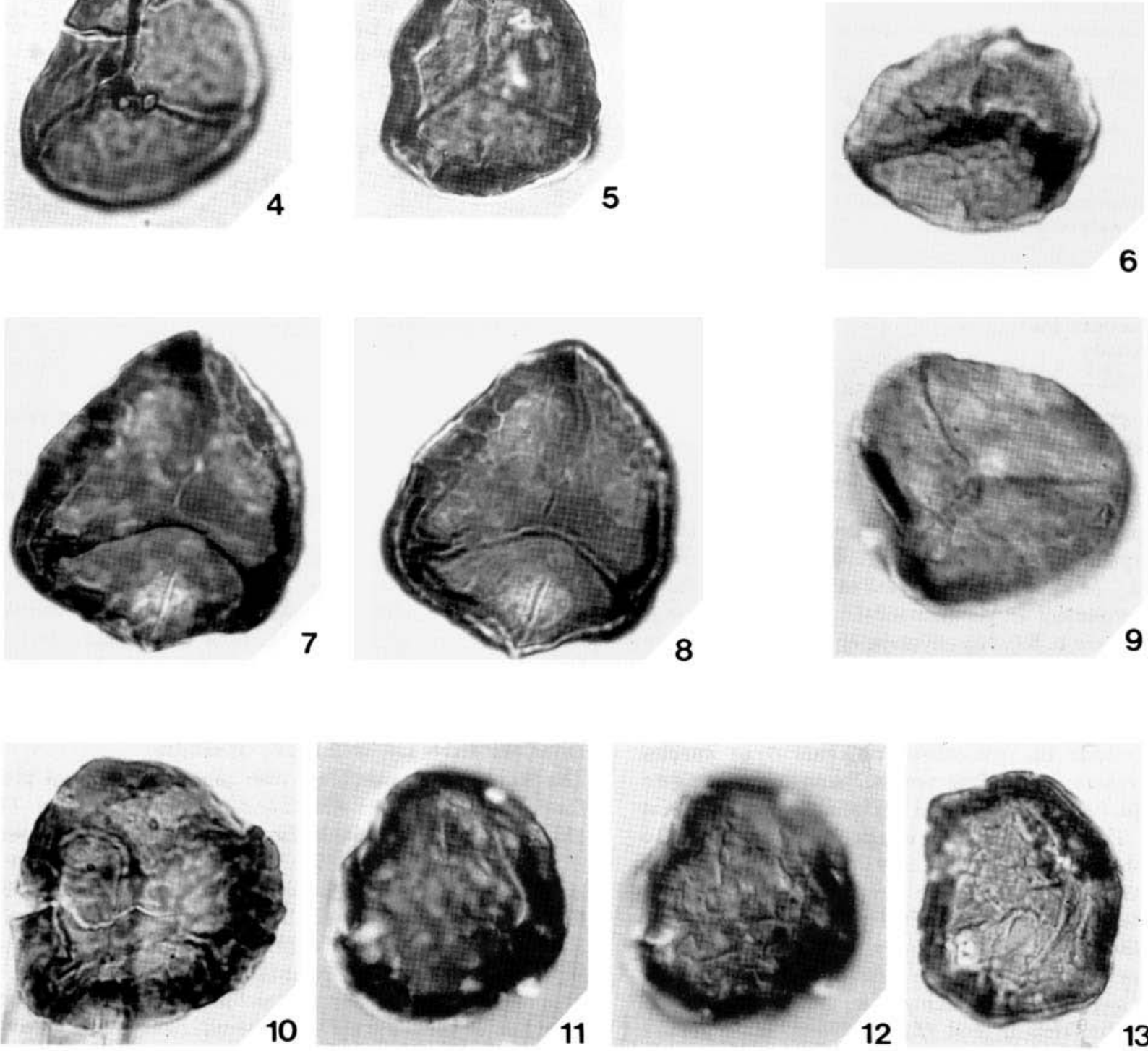


\section{TABLE 1}

Sporomorph Taxa recorded fromthe Stonehaven Assemblage

\section{TRILETE SPORES}

Ambitisporites avitus Hoffmeister, 1959

Ambitisporites dilutus (Hoffmeister) Richardson \& Lister, 1969

Synorisporites spp.

Archaeozonotriletes chulus (Cramer) Richardson \& Lister, 1969

Chelinospora? sp.A

Cymbosporites sp.A

\section{CRYPTOSPORES}

Alete cryptospore monads

Laevolancis divellomedium (Chibrikova) Burgess \& Richardson, 1991

Laevolancis plicata Burgess \& Richardson, 1991

Artemopyra brevicosta Burgess \& Richardson, 1991

Artemopyra sp.A Burgess\& Richardson, 1991

Hispanaediscus lamontii sp. nov.

Hispanaediscus verrucatus? (Cramer) Burgess \& Richardson, 1991

Hispanaediscus wenlockensis Burgess \& Richardson, 1991

Dyadospora murusattenuata (Strother \& Traverse) Burgess \& Richardson, 1991

Dyadospora murusdensa (Strother \& Traverse) Burgess \& Richardson, 1991

Pseudodyadospora petasus Wellman \& Richardson, 1993

Cheilotetras caledonica Wellman \& Richardson, 1993

Tetrahedraletes medinensis (Strother \& Traverse) Wellman \& Richardson, 1993

\section{INCERTAE SEDIS}

?Tetrads of laevigate trilete spores

Murornate tetrads

comprise $8 \%$ of the sporomorph content, but the ornamented forms did not feature in the counts. Tetrads of laevigate sporomorphs, which are probably tetrads of trilete spores, are also present.

Cryptospore tetrads are represented by the naked, unfused species T.medinensis and the fused species C.caledonica. Naked, unfused tetrads with a distal murornate ornament are problematical and described under incertae sedis (see p. 58). No envelope enclosed cryptospore tetrads were recorded. Cryptospore tetrads comprise $18 \%$ of the assemblage \{T.medinensis (17\%), C.caledonica (1\%), and the enigmatic murornate tetrads $(<1 \%)$ \}.

Dyads include the smooth-walled, true dyad species D.murusattenuata and D.murusdensa, and the laevigate pseudodyad P.petasus. Envelope enclosed dyads were not recorded. The true dyads comprise $20.5 \%$ of the sporomorphs and pseudodyads only $0.5 \%$.

The hilate cryptospores are predominantly laevigate forms of the genus Laevolancis which can be assigned to the species L.divellomedium and L.plicata. Rare specimens with rudimentary sculpture are also present. A.brevicosta and Artemopyra sp.A Burgess \& Richardson, 1991 have incipient proximal radial ribbing and H.wenlockensis, H.verrucatus? and H.lamontii sp.nov. have a distal ornament of verrucae and/or muri. In a count hilate cryptospores constituted $23 \%$

\section{Table 2}

Sporomorph morphotype frequency count for 200 specimens from sample AS12.

$\begin{array}{cl}\text { SPOROMORPH } & \% \\ \text { TRILETE SPORES } & 8.0 \\ \text { Crassitate, Laevigate } & 7.0 \\ \text { Crassitate, Ornamented } & \mathrm{P} \\ \text { Patinate, Laevigate } & 1.0 \\ \text { Patinate Ornamented } & \mathrm{P}\end{array}$

\section{CRYPTOSPORES}

87.5

Laevigate Hilate Cryptospores

Ornamented Hilate Cryptospores $\quad 1.0$

True Dyads

Pseudodyads

20.5

Permanent Tetrads

0.5

Alete Cryptospore Monads

18.0

25.5

\section{INCERTAE SEDIS}

Murornate Tetrads

?Tetrads of Trilete Spores

$\mathrm{P}=$ present but not featured in counts of the palynomorphs, but the sculptured forms comprised only $1 \%$ of the assemblage.

Alete cryptospore monads (P1.3, Figs 9-11), often with rather thin, folded walls, constituted $25.5 \%$ of the assemblage. They have a size range of between 28 and $62 \mu \mathrm{m}$ and probably originate from more than one source. These palynomorphs are of uncertain origin and although many may be subaerially dispersed propagules derived from some form of land plant, some are possibly derived from aquatic organisms, such as protists, which inhabited the water body in which the palynomorph assemblage accumulated.

\section{DESCRIPTION OF THE PHYTODEBRIS}

The Stonehaven assemblage also contains dispersed plant fragments (cuticle-like sheets and tubular structures). The affinities of these fragments has been extensively discussed in recent years (Banks 1975; Gray \& Boucot 1977; Pratt et al.1978; Strother \& Traverse 1979; Edwards 1982, 1986; Edwards \& Rose 1984; Gray 1985; Johnson 1985; Burgess \& Edwards 1991; Gensel et al.1991). Because such fragments have been recovered from non-marine deposits and are, in general character, similar to structures present in fossil and extant land plants, they are generally considered derived from some form of land plant.

The cuticle-like sheets recovered from the Stonehaven 
assemblage consist largely of forms which are smooth on one surface and have an irregular reticulate pattern of ridges on the other. The units of most sheets are polygonal, although in some fragments they are circular in outline. The units generally vary in size on individual sheets and do not form any recognisable patterns. The sheets are up to $300 \mu \mathrm{m}$ in diameter but margins have not been observed. Perforations, if any, are mostly interpreted as the result of abrasion because the margins are usually irregular and are often torn, although in some rare cases they may be primary. Similar sheets have been reported from at least the Caradoc to the Lower Devonian (Pratt et al 1978; Strother \& Traverse 1979; Gray et al.1982; Edwards 1982,1986; Edwards \& Rose 1984; Edwards \& Burgess 1991; Gensel et al.1991). Ornamented sheets such as those reported from the Lochkovian by Edwards \& Rose (1984) and Edwards(1986) were not recorded.

The tubular structures include unornamented and internally thickened types. A system of nomenclature and classification has recently been proposed for dispersed tubular structures (Burgess \& Edwards 1991) and most of the taxa present in the Stonehaven assemblage are described in this work and are listed in Table 3. However, several of the tube forms which are present have not been systematically named, although similar tubes have previously been figured and/or described. These include tubular structures with an internal ornament of microthickenings, which are less than $1 \mu \mathrm{m}$ high, wide and apart, and are arranged in either a helical or annular pattern (see Pratt et al.1978; Strother \& Traverse 1979; Burgess \& Edwards 1991; Wellman \& Richardson 1993), and tubular structures with an internal ornament of closely spaced, low, wide thickenings, which are up to $3 \mu \mathrm{m}$ wide, less than $1 \mu \mathrm{m}$ high and less than $0.5 \mu \mathrm{m}$ apart, and are arranged in an anastomosing pattern (see Wellman \& Richardson 1993). Additionally, rare associations of tubes are present which comprise a wide tube enclosed within a mesh of smaller tubes. Such associations are believed to be fragments derived from the nematophyte Prototaxites and are referred to as Prototaxites? sp. (see Edwards 1982; Wellman \& Richardson 1993).

The assemblage of tubular structures recovered from the Stonehaven Group is almost identical to the set of tubular structures reported by Burgess \& Edwards (1991) from deposits of Mid Silurian age from the Anglo-Welsh Basin. The only major difference is the absence of the externally thickened tube Constrictitubulus cristatus Burgess and Edwards, 1991 and the filament Ornatifilum granulatum Burgess \& Edwards, 1991 from the Stonehaven assemblage.

\section{AGE OF THE ASSEMBLAGE AND CORRELATION WITH SPOROMORPH ZONAL SCHEMES}

The features of the Stonehaven assemblage which are of most significance for age dating are-

1) the presence of rare trilete spores and hilate cryptospores with rudimentary sculpture

2) the absence of a diverse array of ornamented

\section{Table 3}

Tubular Structures recorded fromthe Stonehaven Assemblage

Laevitubulus plicata Burgess\& Edwards, 1991

Laevitubulus tenuis Burgess \& Edwards, 1991

Laevitubulus crassus Burgess \& Edwards, 1991

Laevitubulus laxus Burgess \& Edwards, 1991

Porcatitubulus annulatus Burgess \& Edwards, 1991

Porcatitubulus spiralis Burgess \& Edwards, 1991 (almost exclusively with a single helical internal thickening).

Tubes with an internal ornament of closely spaced microthickenings which are arranged in either a helical or annular pattern.

Tubes with an internal ornament of closely spaced, low, wide thickenings which are arranged in an anastomosing pattern.

Prototaxites? sp.

sporomorphs, particularly trilete spores with 'advanced' forms of ornament such as well defined proximal radial ribbing

3) the domination of the assemblage by cryptospores, notably laevigate hilate cryptospores, true dyads and permanent tetrads.

In the Anglo-Welsh Basin, simple ornamented hilate cryptospores and miospores make their inception in the earliest Homerian (upper lundgreni Graptolite Biozone) (Burgess \& Richardson 1991). The hilate cryptospore ornament consists of proximal radial ribbing, distal perforations, and distal murornate sculpture, whereas the miospore ornament is confined to distal murornate sculpture and weakly defined proximal muri. Older sporomorph assemblages from strata of late Llandoveryearly Wenlock age from the Anglo-Welsh Basin contain only laevigate miospores and hilate cryptospores (Burgess 1991; Burgess \& Richardson 1991). A potential slightly earlier record of sculptured miospores is from sediments of late Sheinwoodian to earliest Homerian age (ellesae-lundgreni Graptolite Biozone) from the Southern Uplands of Scotland (Barron 1989). Hence the presence of rare sculptured hilate cryptospores and miospores in the Stonehaven assemblage suggests a lower age limit of latest Sheinwoodian to earliest Homerian (ellesae-lundgreni Graptolite Biozone).

Reports of sporomorph distribution in Silurian deposits from southern Britain (Richardson \& Lister 1969; Burgess 1987), North Africa (Richardson \& Ioannides 1973) and North America (McGregor \& Narbonne 1978; Wood 1978) demonstrate that sculptured miospores and hilate cryptospores increase in variety and abundance throughout the late Wenlock \& Ludlow. Particularly noteworthy is the incoming of trilete spores with well defined proximal radial ribs in the early Ludlow (nilssoni Graptolite Biozone) and sporomorphs with apiculate sculpture slightly higher in the Ludlow (Richardson \& Edwards 1989). Comparison with descriptions of early Ludlow sporomorph assemblages (Richardson \& Lister 1969; Richardson \& Ioannides 1973; Burgess 1987) suggests that the Stonehaven assemblage is not younger than earliest Ludlow in age because it contains 
a low abundance and diversity of ornamented spores which exhibit very rudimentary forms of sculpture which are less 'advanced' than those present in the post earliest Ludlow age assemblages.

However, the similarity between the Stonehaven assemblage and sporomorph assemblages described by Burgess \& Richardson (1991) from the type area for the Upper Wenlock is striking. Of the 18 sporomorph species recorded from the Upper Wenlock assemblages of southern Britain, 15 of these are present in the Stonehaven assemblage. Additionally, the overall nature of the Stonehaven assemblage, for example the paucity of ornamented forms and the abundance of cryptospores (particularly laevigate permanent tetrads, true dyads and hilate cryptospores), is characteristic of sporomorph assemblages of late Wenlock age, for example those described from the Upper Wenlock of southern Britain (Burgess \& Richardson 1991). This suggests that the Stonehaven assemblage is most likely late Wenlock in age, although an earliest Ludlow age cannot be discounted.

In terms of the sporomorph zonation scheme of Richardson \& McGregor (1986), the Stonehaven assemblage can be assigned to the Artemopyra brevicosta (?E.cf.protophanus)-Hispanaediscus verrucatus (cf.S.verrucatus) Assemblage Biozone (Richardson \& McGregor 1986; Richardson \& Edwards 1989; Burgess \& Richardson 1991). This zone is of early Homerian-earliest Gorstian age, based largely on work in the Welsh Borderland. Most of the diagnostic features of this zone can be recognised in the Stonehaven assemblage and many of the characteristic species, including the nominal species, are present. The sculptural innovations which characterise the succeeding libycuspoecilomorphus Assemblage Biozone, for example miospores with prominent proximal radial ribs, are not displayed in the Stonehaven assemblage. Regarding the biostratigraphical scheme proposed by Gray (1985), the Stonehaven assemblage can be correlated with Microfossil Assemblage Zone III (late? Wenlock-Pridoli).

\section{COMPARISON WITH PREVIOUSLY DESCRIBED SPOROMORPH ASSEMBLAGES OF LATE WENLOCK- EARLY LUDLOW AGE}

Sporomorph assemblages of Mid Silurian age have been described from southern Britain, Scotland, Spain, Libya and North America. They are all similar and can be closely matched with the Stonehaven assemblage. They all contain miospores and hilate cryptospores that are predominantly smooth walled, but include rare ornamented forms. The ornament is basic and consists of distal verrucae, muri or perforations, and proximal radial ribs. In the cases where cryptospores have been described, smooth walled permanent tetrads, true dyads, hilate cryptospores and alete cryptospore monads are present and tend to dominate the assemblages. Envelope enclosed sporomorphs are usually absent or very rare.

Sporomorphs from Wenlock \& Ludlow strata of southern Britain have been reported by Downie (1963), Richardson \& Lister (1969) and more recently by Burgess \& Richardson (1991). In their initial examination of spores in the AngloWelsh Basin, Richardson \& Lister(1969) noted that spore diversity and ornament complexity increased through the Wenlock \& Ludlow. The earliest ornamented forms, H.verrucatus (as cf.Synorisporites verrucatus) and possibly Archaeozonotriletes chulus var.inframurinatus, were recovered from the Much Wenlock Limestone Formation (as Wenlock Limestone) of Homerian age. These ornamented forms were 
accompanied by laevigate miospores which were either crassitate or patinate. Further species of ornamented sporomorphs were present in strata of Ludlow age, often displaying more complex varieties of sculpture.

Subsequently, Burgess \& Richardson(1991) re-examined the sporomorph sequence in the type area for the Wenlock. The earliest sculptured spores they recorded were the hilate cryptospores A.brevicosta (sometimes united in dyads) and H.verrucatus which first appear in the upper lundgreni Graptolite Biozone. These ornamented forms co-exist with the cryptospores T.medinensis, D.murusattenuata, D.murusdensa, L.divellomedium, L.plicata and the miospores A.dilutus and A.chulus vars. chulus and nanus. Slightly higher in the sequence H.wenlockensis, cf.Hispanaediscus sp.A, Artemopyra sp.A, Hilate Spore Type 1, murornate tetrads, and the miospores Synorisporites cf.S. ?libycus and Trilete Spore Type 1 were reported. This assemblage is very similar to the one described from Stonehaven and most of the taxa reported have been recognised in the Stonehaven assemblage.

In Scotland, the earliest recorded sculptured miospore is cf.Synorisporites verrucatus from the Greyhound Law inlier of the Cheviot Hills (Barron 1989). Graptolites and acritarchs indicate that the strata is of late Sheinwoodianearliest Homerian age (ellesae-lungreni Graptolite Biozone). Sporomorphs are rare in the material but A.avitus, A.dilutus, A.chulus var.nanus, D.murusdensa and T.medinensis were also recovered. The figured specimen of cf.S.verrucatus is clearly trilete with a distal ornament of verrucae.

Richardson \& Ioannides (1973) described some exquisitely preserved spore assemblages from the subsurface of Libya. Graptolite evidence suggests a late Wenlock-early Ludlow age at several points in the sequence. However, the succession of sporomorph assemblages is closely similar to that of the Anglo-Welsh Basin and comparisons can be used to refine age constraints (Richardson \& Edwards 1989). The sequence commences with assemblages which comprise entirely smooth-walled miospores and are probably of late Llandovery-early Wenlock age. They are succeeded by assemblages which contain the ornamented forms A.brevicostata (as Emphanisporites cf.protophanus), H.verrucatus (as cf.Synorisporites verrucatus), Synorisporites cf.verrucatus and verrucate tetrads. Comparisons with sporomorph associations from southern Britain suggests that these assemblages are of late Wenlock age. They are succeeding by more complex assemblages which include miospores with proximal radial ribs and are probably of Ludlow age. Miospores with apiculate and foveolate sculpture first appear slightly higher in the sequence.

In southern Europe, Rodriguez (1983) described sporomorph assemblages from the San Pedro-Furada Formation of the Cantabrian Mountains of north-west Spain. The strata are poorly age constrained but the sequence of spore innovations is very similar to that reported from the Anglo-Welsh Basin and many species are apparently common to both regions. Hence some degree of correlation is possible between the two areas. Rodriguez reported only laevigate, crassitate, miospores from the oldest strata sampled which suggests a late Llandoveryearly Wenlock age. The succeeding sporomorph assemblages contain laevigate miospores of the genera Ambitisporites, Archaeozonotriletes and Retusotriletes, and the ornamented species Synorisporites verrucatus and Convolutispora sanpetrense. Rodriguez suggested that the incoming of ornamented miospores probably indicates a late Wenlock age. Assemblages from higher in the sequence exhibit an increasing diversity of ornament type, including trilete spores with proximal radial ribs, and Rodriguez allocated them a Ludlow age.

Strother \& Traverse (1979) described a spore assemblage from Clinton? strata of Pennsylvania, U.S.A. They tentatively attributed a Wenlock age on evidence from field relations. Rare miospores affiliated to Ambitisporites occurred with permanent tetrads (probably Tetrahedraletes $s p$.), true dyads (D.murusattenuata and D.murusdensa), laevigate hilate cryptospores (probably Laevolancis spp.), "sphaeromorphs", and rare ornamented hilate cryptospores. The ornamented hilate cryptospores are represented by specimens with proximal radial ribs which are occasionally observed configurated in dyad form, and specimens with concentrically aligned distal perforations (probably Hilate Cryptospore Type 1 of Burgess \& Richardson (1991)). Comparisons with the distribution of sporomorphs in the Anglo-Welsh Basin (Burgess 1987; Burgess \& Richardson 1991) suggests a late Wenlock-earliest Ludlow age. This paper provided the first description of a sporomorph assemblage of this age from probable nonmarine strata and demonstrated that 1) cryptospores are numerically more abundant than miospores, and 2) ornamented sporomorphs are rare.

It is apparent that sporomorph assemblages which have been attributed a late Wenlock-earliest Ludlow age are all closely comparable. They all exhibit similar characteristics and contain many common species. Furthermore, the sequence of sporomorph innovations and first appearances in strata of Llandovery through to Ludlow age is seen to be very similar in successions from southern Britain, Spain and North Africa. However, it is important to note that early reports of Silurian sporomorphs were compiled before the recognition of cryptospores which were consequently overlooked in many of these publications.

\section{GEOLOGICAL SIGNIFICANCE}

The age constraint provided by the sporomorph assemblage provides a reliable age for the fauna of the Cowie Harbour fish bed and has important implications regarding the regional geology of the area and tectonic modelling of the Midland Valley during the Silurian.

The fish bed occurs in the upper part of the Cowie Formation and contains an important and diverse fauna which has previously been regarded as Downtonian (Pridoli) in age (Campbell 1913; Westoll 1951). The inland 
exposures from which the spore assemblages were recovered are lithologically similar to the Cowie Formation and are correlated with it (Campbell 1913), suggesting that the fish bed is of late Wenlock, or possibly earliest Ludlow age. This implies that the Downtonian age assignment which was based on the fish and arthropod fauna is incorrect, as Lamont (1952) and Janken \& Størmer (1975) suspected. The inaccuracy of this age designation is probably a consequence of using poorly defined taxa whose distribution is likely to be strongly facies controlled.

Regarding palaeoenvironmental determination, the Stonehaven assemblage comprises entirely palynomorphs interpreted as land-derived suggesting that the assemblage accumulated in a non-marine environment. Therefore the microfossil evidence corroborates interpretations based on sedimentological evidence which indicate that the Stonehaven Group deposits are fluvial in origin (Armstrong et al.1978; Gillen \& Trewin 1987).

The new age constraint also prompts a reconsideration of the relationship of the Stonehaven Group with the overlying strata. The Dunnottar Group was previously thought to succeed the Stonehaven Group with minor unconformity and the Stonehaven Group was therefore regarded as the lowermost strata of the "Lower Old Red Sandstone" sequence in the northern part of the Midland Valley. The new age data demonstrates that a much larger time interval than previously recognised existed between deposition of the Cowie Formation and the next well dated overlying strata, in the Arbuthnott Group, which is considered to be of early Gedinnian age on the basis of spore data (Richardson et al.1984). A maximum of $2000 \mathrm{~m}$ of strata separates the two age constrained levels. As there are no obvious breaks in sedimentation within the Dunnottar, Crawton or lowermost Arbuthnott Groups, it seems likely that the junction between the Stonehaven Group and the Dunnottar Group may constitute a significant paraconformity or unconformity, or may even be faulted. Evidence from sedimentology is supportive of this theory (see p. 2). Thus the Silurian strata of the Stonehaven Group appears to be unrelated to the overlying "Lower Old Red Sandstone" deposits and the two sets of strata probably did not accumulate as a near continuous sequence in the same basin as was previously believed. The obvious location for the junction between the Silurian Stonehaven Group deposits and the "Lower Old Red Sandstone" deposits is the gap in exposure in the coast section near the mouth of the River Carron (see p. 2).

The new age data demonstrates that continental sedimentation commenced in the northern part of the Midland Valley by at least late Wenlock-earliest Ludlow times. This is comparable to the circumstances in the southern part of the Midland Valley where continental sedimentation was initiated by early Wenlock times (Wellman \& Richardson 1993). The Silurian inliers located along the southern margin of the Midland Valley all exhibit similar regressive sequences that commence with deep marine turbiditic sediments, which are succeeded by shallow marine sediments of latest Llandovery or early Wenlock age, and eventually culminate in red bed sequences of terrestrial-fluviatile origin, which are in part of early Wenlock age. The red bed sequences of the inliers are overlain with either unconformity or paraconformity by "Lower Old Red Sandstone" continental deposits which are believed to be of early Devonian age. The deposits present in the inliers are interpreted as having accumulated in an elongate basin which gradually infilled. The actual tectonic scenario is contentious, but is clearly intimately related to the complex tectonic events associated with the southern margin of the Laurasia continent which was destructive throughout the Silurian. The basin has been interpreted as an interarc basin (Bluck 1983) or an upper slope basin (Leggett 1980). The new age data suggests that the Stonehaven Group may be a correlative of part of the red bed sequence present in the southern Midland Valley Silurian inliers, and may have accumulated in the same basin. If this is the case, the Stonehaven Group may have a similar relationship with the overlying "Lower Old Red Sandstone" deposits as do the red beds in the southern Midland Valley inliers.

\section{PALAEOBOTANICAL SIGNIFICANCE}

The Stonehaven assemblage is important palaeobotanically because it is only the second reported plant microfossil assemblage of late Wenlock-earliest Ludlow age which is derived from continental deposits. The other report is from the ?Clinton strata of Pennsylvania (Strother and Traverse 1979) (see p. 63). Particularly noteworthy are comparisons of the abundance of the various sporomorph morphotypes in these two assemblages. Interestingly, they conform closely in that cryptospores comprise the bulk of the sporomorphs and miospores constitute a rather minor component (see Table 2). Furthermore, ornamented sporomorphs are rare in both assemblages, constituting less than $2 \%$ of the total palynomorphs in the Stonehaven assemblage. Such observations have been masked in previous reports of sporomorph assemblages of this age because firstly, cryptospores have frequently been overlooked, and secondly, it is difficult to gauge relative abundances of sporomorph morphotypes in marine assemblages because sporomorphs are often rare and have experienced extensive sorting during transportation.

The Stonehaven assemblage augments the growing number of reports of Mid-Silurian sporomorph associations. The present database suggests that sporomorph assemblages of this age are all very similar in composition. This implies that the sporomorphs, like those from the Lower Wenlock (Wellman \& Richardson 1993), were derived from a widespread and cosmopolitan flora. Furthermore, the lack of diversity displayed by the sporomorph associations (approximately 21 species in the Stonehaven assemblage) indicates that the flora was not diverse and comprised few taxa.

Recent in situ spore studies have demonstrated that the late Silurian rhyniophytoid plant Cooksonia produced 
simple trilete spores, and similar Salopella-like plants with elongate terminal sporangia produced hilate cryptospores united in true dyads (Fanning et al.1991). The earliest example of Cooksonia is reported from strata of late Wenlock age from Ireland (Edwards et al.1983) and it is tempting to envisage the late Wenlock vegetation comprising a few species of simple rhyniophytoid plants which produced the trilete spores, hilate cryptospores and related true dyads, and possibly also the other cryptospore morphotypes. Unfortunately, however, permanent tetrads, pseudodyads and alete cryptospore monads have not yet been reported in situ.

The dispersed plant fragments present in the Stonehaven assemblage are remarkably similar to those from previously described assemblages of Mid Silurian age (see p. 61). This suggests that the plants from which these fragments derive had a widespread and cosmopolitan distribution and constituted an important element of the vegetation. Unfortunately the affinities of these structures remains equivocal although it is possible that they derive from some form of thalloid land plant (Edwards 1982; Strother 1988; Gensel et al.1991).

\section{ACKNOWLEDGEMENTS}

This work was undertaken during the tenure of a NERC postgraduate studentship that was a CASE award held jointly between the Department of Geology of the University of Wales (College of Cardiff) and the Department of Palaeontology of the Natural History Museum, London. I would like to express my gratitude to Prof. Dianne Edwards and Dr. John Richardson for their supervision.

\section{Manuscript received March 1992 \\ Manuscript accepted January 1993}

\section{REFERENCES}

Armstrong, M. and Paterson, I.B. 1970. The Lower Old Red Sandstone of the Strathmore region. Inst. Geol. Sci. Rep. 70/12, 1-28.

Armstrong, M., Donovan, R.N. and Paterson, I.B. 1978. Angus and Kincardine. In Friend, P.F. and Williams, B.P.J. (Eds.), A field guide to selected outcrop areas of the Devonian of Scotland, the Welsh Borderland and South Wales, 13-22. Palaeontological Association.

Banks, H.P. 1975. The oldest vascular land plants: a note of caution. Rev. Palaeobot. Palynol, 20, 13-25.

Barron, H.F. 1989. Mid-Wenlock acritarchs from a Silurian inlier in the Cheviot Hills, North-east England. Scott. J. Geol., 25(1), 81-98.

Bluck, B.J.1983. Role of the Midland Valley of Scotland in the Caledonian Orogeny. Trans. Roy. Soc. Edinburgh, Earth Sci., 74, 119-136.

Burgess, N.D. 1987. Micro- and megafossils of land plants from the Silurian and Lower Devonian of the Anglo-Welsh Basin. Unpublished PhD thesis, University of Wales.

Burgess, N.D. 1991. Silurian cryptospores and miospores from the type Llandovery area south-west Wales. Palaeontology, 34(3), 575-599.
Burgess, N.D. and Edwards, D. 1991. Classification of uppermost Ordovician to Lower Devonian tubular and filamentous macerals from the Anglo-Welsh Basin. Bot. Journ. Linnaean Soc., London 106, 41-66.

Burgess, N.D. and Richardson, J.B. 1991. Silurian cryptospores and miospores from the type Wenlock area, Shropshire, England. Palaeontology, 34(3), 601-628.

Campbell, R. 1911. Preliminary note on the geology of southeast Kincardineshire. Geol. Mag., 8, 63-69.

Campbell, R. 1913. The geology of south-east Kincardineshire. Trans. R. Soc. Edinburgh, 48, 923-960.

Downie, C. 1963. 'Hystrichospheres' (acritarchs) and spores of the Wenlock Shale (Silurian) of Wenlock, England. Palaeontology, 6, 625-652.

Edwards, D. 1982. Fragmentary non-vascular plant microfossils from the late Silurian of Wales. Bot. Journ. Linnaean Soc., London, 84, 223-256.

Edwards D. 1986. Dispersed cuticles of putative non-vascular plants from the Lower Devonian of Britain. Bot. Journ. Linnaean Soc., London, 93, 259-275.

Edwards, D. and Burgess, N.D. 1991. Terrestrialization: plants. In: Briggs, D.E.G. and Crowther, P.R. (Eds.), Palaeobiology: $A$ Synthesis, 60-63. Blackwell Scientific Publications.

Edwards, D., Feehan, J. and Smith, D.G. 1983. A late Wenlock flora from Co. Tipperary, Ireland. Bot. Journ. Linnaean Soc., London, 86, 19-36.

Edwards, D. and Rose, V. 1984. Cuticles of Nematothallus: a further enigma. Bot. Journ. Linnaean Soc., London, 88, 35-54.

Fanning, U., Richardson, J.B. and Edwards, D. 1991. A review of in situ spores in Silurian land plants. In: Blackmore, S. and Barnes, S. (Eds.), Pollen and Spores, Systematics Association Special Volume No.44, 25-47. Clarendon Press, Oxford.

GenselL, P.G., Johnson, N.G. and Strother, P.K. 1991. Early land plant debris (hooker's "waifs and strays"?). Palaios., 5, 520547.

Gillen, C. and Trewin, N.H. 1987. Dunnottar to Stonehaven and the Highland Boundary Fault. In: Trewin, N.H., Kneller, B.C. and Gilen, C. (Eds.), Excursion Guide to the Geology of the Aberdeen Area, 265-273. Scottish Academic Press, Edinburgh.

Gray, J. 1985. The Microfossil record of early land plants; advances in understanding of early terrestrialization 19701984. Phil. Trans. R. Soc., London, 309B, 167-195.

Gray, J. 1991. Tetrahedraletes, Nodospora, and the 'cross' tetrad: an accretion of myth. In BLACKMORE, S. and BARNES, S.H. (Eds.), Pollen and Spores, Systematics Association Special Volume No.44, 49-87, Clarendon Press, Oxford.

Gray, J. and Boucot, A.J. 1977. Early vascular land plants: proof and conjecture. Lethaia, 10, 145-174.

Gray, J., Massa, D. and Boucot, A.J. 1982. Caradocian land plant microfossils from Libya. Geology, 10, 197-201.

Grebe, H. 1971. A recommended terminology and descriptive method for spores. CIMP Special Volume 4, Microfossiles organique du Pal ${ }^{*}$ ozoique, 7-34.

Hanken, N.M. and Størmer, L. 1975. The trail of a large Silurian eurypterid. Fossils and Strata, 4, 255-270.

Johnson, N.G. 1985. Early Silurian palynomorphs from the Tuscarora Formation in central Pennsylvania and their palaeobotanical and geological significance. Rev. Palaeobot. Palynol., 45, 307-360.

Lamont, A. 1952. Ecology and correlation of the Pentlandian -a new division of the Silurian system in Scotland. Report of the 
International Geological Congress XV111, London 1948, part X, 27-32.

Leggett, J.K. 1980. The sedimentological evolution of a lower Palaeozoic accretionary fore-arc in the Southern Uplands of Scotland. Sedimentology, 27, 401-417.

Marshall, J.E.A. 1991. Palynology of the Stonehaven Group, Scotland; evidence for a Mid Silurian age and its geological implications. Geol. Mag., 128(3), 283-286.

McGregor, D.C. and Narbonne, G.M. 1978. Upper Silurian spores and other microfossils from the Read Bay Formation, Cornwallis Island, Canadian Arctic. Can. Journ. Earth Sci., 15, 1292-1303.

Pratt, L.M., Phillips, T.L. and Dennison, J.M. 1978. Evidence of non-vascular land plants from the early Silurian (Llandovery) of Virginia U.S.A. Rev. Palaeobot. Palynol, 25, 121-149.

Richardson, J.B. and Edwards, D. 1989. Sporomorphs and plant megafossils. In: Holland, C.H. and Bassett, M.G. (Eds.), A global standard for the Silurian system, National Museum of Wales Geological Series No.9, 216-226, Cardiff.

Richardson, J.B., Ford, J.H. and Parker, F. 1984. Miospore, correlation and age of some Scottish Lower Old Red Sandstone sediments from the Strathmore region (Fife and Angus). Journ. Micropalaeontology, 3(2), 109-124.

Richardson, J.B. and Ioannides, N. 1973. Silurian palynomorphs from the Tanezzuft and Acacus Formations, Tripolitania, North Africa. Micropalaeontology, 19(3), 357-307.

Richardson, J.B. and Lister, T.R. 1969. Upper Silurian and lower Devonian spore assemblages from the Welsh Borderland and
South Wales. Palaeontology, 12(2), 201-252.

Richardson, J.B. and McGregor, D.C. 1986. Silurian and Devonian spore zones of the Old Red Sandstone continent and adjacent regions. Geol. Surv. Canada Bull, 364, 79p.

Rodriguez, R.M. 1983. Palynología de las formaciones del Siluro superior-Devonica inferior de la Cordillera Cantábrica. Publicaciones Universidad de Léon (España), 231p.

Strother, P.K. 1988. New species of Nematothallus from the Silúrian Bloomsburg Formation of Pennsylvania. Journ. Paleontology, 62(6), 967-982.

Strother, P.K. 1991. A classification schema for the cryptospores. Palynology, 15, 4-20.

Strother, P.K. and Traverse, A. 1979. Plant microfossils from Llandovery and Wenlock rocks of Pennsylvania. Palynology, 3, 1-21.

Wellman, C.H. 1991. Land-derived palynomorphs from Silurian and Lower Devonian deposits of Scotland. Unpublished PhD Thesis, University of Wales (College of Cardiff).

Wellman, C.H. and Richardson, J.B. 1993. Terrestrial plant microfossils from Silurian inliers of the Midland Valley of Scotland. Palaeontology, 36, 155-193.

Westoll, T.S. 1951. The vertebrate-bearing strata of Scotland. Report of the International Geological Congress XV111, London 1948, part X1, 5-21.

Wood, G.D. 1978. Silurian trilete spores and fragments from northern Indiana and their paleobotanical implications. Micropalaeontology, 24, 327-331.

\section{APPENDIX 1}

Location of Samples

SAMPLE
NUMBER

AS12

AS16

\section{LOCATION}

Exposure in the west bank of the Burn of Graham $20 \mathrm{~m}$ north of the Bridge of Graham.

Exposure on the north bank of Carron Water opposite the first major bend north of the Railway Bridge.
GRID

REFERENCE

NO82578538

NO82148514 